\title{
Taehwa Research Forest: a receptor site for severe domestic pollution events in Korea during 2016
}

\author{
John T. Sullivan ${ }^{1}$, Thomas J. McGee ${ }^{1}$, Ryan M. Stauffer ${ }^{1,2}$, Anne M. Thompson ${ }^{1}$, Andrew Weinheimer ${ }^{3}$, \\ Christoph Knote ${ }^{4}$, Scott Janz ${ }^{1}$, Armin Wisthaler ${ }^{5,6}$, Russell Long ${ }^{7}$, James Szykman ${ }^{7,8}$, Jinsoo Park ${ }^{9}$, Youngjae Lee ${ }^{9}$, \\ Saewung Kim ${ }^{10}$, Daun Jeong ${ }^{10}$, Dianne Sanchez ${ }^{10}$, Laurence Twigg ${ }^{1,11}$, Grant Sumnicht ${ }^{1,11}$, Travis Knepp ${ }^{8,12}$, and \\ Jason R. Schroeder ${ }^{13}$ \\ ${ }^{1}$ Atmospheric Chemistry and Dynamics Laboratory, NASA Goddard Space Flight Center, Greenbelt, MD 20771, USA \\ ${ }^{2}$ Universities Space Research Association, Columbia, MD 21046, USA \\ ${ }^{3}$ National Center for Atmospheric Research, Boulder, CO 80305, USA \\ ${ }^{4}$ Meteorologisches Institut, Ludwig-Maximilians-Universität München, München, Germany \\ ${ }^{5}$ Department of Chemistry, University of Oslo, Oslo, Norway \\ ${ }^{6}$ Institute for Ion Physics and Applied Physics, University of Innsbruck, Innsbruck, Austria \\ ${ }^{7}$ US EPA/Office of Research and Development/National Exposure Research Lab, Research Triangle Park, NC 27711, USA \\ ${ }^{8}$ NASA Langley Research Center, Hampton, VA 2368, USA \\ ${ }^{9}$ National Institute of Environmental Research, Incheon, South Korea \\ ${ }^{10}$ Department of Earth System Science, University of California, Irvine, Irvine, CA, USA \\ ${ }^{11}$ Science Systems and Applications, Inc., Lanham, MD 20706, USA \\ ${ }^{12}$ Science Systems and Applications, Inc., Hampton, VA 23666, USA \\ ${ }^{13}$ California Air Resources Board, Sacramento, CA 95814, USA
}

Correspondence: John T. Sullivan (john.t.sullivan@ nasa.gov)

Received: 20 December 2018 - Discussion started: 14 January 2019

Revised: 12 March 2019 - Accepted: 14 March 2019 - Published: 12 April 2019

\begin{abstract}
During the May-June 2016 International Cooperative Air Quality Field Study in Korea (KORUS-AQ), light synoptic meteorological forcing facilitated Seoul metropolitan pollution outflow to reach the remote Taehwa Research Forest (TRF) site and cause regulatory exceedances of ozone on 24 days. Two of these severe pollution events are thoroughly examined. The first, occurring on 17 May 2016, tracks transboundary pollution transport exiting eastern China and the Yellow Sea, traversing the Seoul Metropolitan Area (SMA), and then reaching TRF in the afternoon hours with severely polluted conditions. This case study indicates that although outflow from China and the Yellow Sea were elevated with respect to chemically unperturbed conditions, the regulatory exceedance at TRF was directly linked in time, space, and altitude to urban Seoul emissions. The second case studied, which occurred on 9 June 2016, reveals that increased levels of biogenic emissions, in combination with amplified urban emissions, were associated with severe
\end{abstract}

levels of pollution and a regulatory exceedance at TRF. In summary, domestic emissions may be causing more pollution than by transboundary pathways, which have been historically believed to be the major source of air pollution in South Korea. The case studies are assessed with multiple aircraft, model (photochemical and meteorological) simulations, in situ chemical sampling, and extensive ground-based profiling at TRF. These observations clearly identify TRF and the surrounding rural communities as receptor sites for severe pollution events associated with Seoul outflow, which will result in long-term negative effects to both human health and agriculture in the affected areas. 


\section{Introduction}

The spatiotemporal characteristics of ozone $\left(\mathrm{O}_{3}\right)$, nitrogen dioxide $\left(\mathrm{NO}_{2}\right)$ and other urban pollutants have been monitored at the ground level within the Seoul Metropolitan Area (SMA) and throughout the Republic of Korea (commonly referred to as South Korea) for several decades (Seo et al., 2014). Although transboundary transport events from other countries (e.g., China) have been demonstrated (Choi et al., 2014), several studies have clearly illustrated the impacts of domestic pollutants on rural receptor sites downwind of the SMA (Kim et al., 2007; Jeon et al., 2014). Furthermore, negative effects associated with poor air quality in South Korea (Ghim et al., 2005) have been connected with increased mortality rates (Lee et al., 2000), and reduction in agricultural yields (Wang and Mauzerall, 2004).

Recent work with high-resolution satellite records from Duncan et al. (2016) indicate a decreasing trend in tropospheric $\mathrm{NO}_{2}$ columns throughout the SMA from 2005 to 2014 that has been attributed to regulatory (e.g., vehicular) controls or a transition to low- or zero-emissions vehicles (Wang et al., 2014). However, during this same time period, the observed trend has increased near the petrochemical and industrial regions to the west and southwest of the SMA. Therefore, due to the complexities and heterogeneity of emissions within the SMA (Vellingiri et al., 2015), it is important to assess chemical gradients that may occur among sites with varying distances from emission sources (Ryu et al., 2013; Iqbal et al., 2014; Jeon et al., 2014; Lee et al., 2014), including sites that may be rural pollution receptor sites.

While a dense network of ground level observations over South Korea exists to monitor pollution, information regarding $\mathrm{O}_{3}$ and its precursors (e.g., oxides of nitrogen; volatile organic compounds or VOCs, including biogenic VOCs or BVOCs) above the surface has been sparse. Because of the lack of chemical profiles, it is difficult to characterize $\mathrm{O}_{3}$ and other pollutants in the air and quantify the impacts of vertical mixing down to the ground level. Analyses of vertical profiles of $\mathrm{O}_{3}$ at the Olympic Park (OLY, $37.5232^{\circ} \mathrm{N}$, $127.1260^{\circ} \mathrm{E}, 26 \mathrm{~m}$ a.s.l.) site within the SMA indicate photochemical $\mathrm{O}_{3}$ production in the afternoon hours corresponding mainly to local precursor advection from upwind regions (the western part of SMA). More recent findings describe the highest $\mathrm{O}_{3}$ events occurring at rural sites $30 \mathrm{~km}$ (Taehwa Forest: TRF, $37.3123^{\circ} \mathrm{N}, 127.3106^{\circ} \mathrm{E}, 160 \mathrm{~m}$ a.s.l.; Kim et al., 2013) and $100 \mathrm{~km}$ (Chuncheon, $37.881^{\circ} \mathrm{N}, 127.676^{\circ} \mathrm{E}$; Jeon et al., 2014) from the SMA. Both of those studies linked the high-pollution events to mobile (vehicular) source emissions in the presence of natural biogenic emissions (i.e., advection of SMA emissions away from their origins and into a highBVOC environment of increased $\mathrm{O}_{3}$ production efficiency).

To further investigate the vertical distribution of pollutants impacting South Korea, the United States (US) National Aeronautics and Space Administration (NASA) and the Korean Ministry of the Environment/Korean National Institute of Environmental Research (NIER) conducted an international cooperative field experiment with sampling at both the TRF and OLY sites, entitled the Korea-US Air Quality (KORUS-AQ, https://espo.nasa.gov/home/korus-aq/ content/KORUS-AQ, last access: 27 March 2019) study. The KORUS-AQ observation period was specifically chosen to target local photochemical pollution (which peaks in MayJune) rather than pollution transport which tends to be greatest in March-April. Differences in daily average $(24 \mathrm{~h}) \mathrm{NO}_{x}$ $\left(\mathrm{NO}+\mathrm{NO}_{2}\right.$, Fig. 1c) and maximum daily hourly $\mathrm{O}_{3}$ (Fig. 1d) during the KORUS-AQ study are presented from 10 May to 11 June 2016. $\mathrm{NO}_{x}$ (which is predominantly $\mathrm{NO}_{2}$ during daytime) can rapidly form $\mathrm{O}_{3}$ in the presence of VOCs and favorable meteorology. The two largest sources within the South Korea $\mathrm{NO}_{x}$ emissions inventory are (1) mobile or vehicular (such as trucks, passenger cars, taxis, motorcycles, totaling $41.7 \%$ ) and (2) "other" mobile sources (such as construction or agricultural machinery, trains, aircraft, ships, totaling 20.0\%) (Lee et al., 2011).

The prevalence of vehicular emissions is apparent in the urban environment (Fig. 1c) with $\mathrm{NO}_{x}$ amounts at OLY frequently an order of magnitude greater than those at rural TRF. Herman et al. (2018) has further shown during the KORUS-AQ study that the difference between TRF (also referred to as Taehwa Mountain) and OLY in columnar $\mathrm{NO}_{2}$ can be as much as 3.0 DU (Dobson units, $1 \mathrm{DU}=2.69 \times 10^{16}$ molecules $\mathrm{cm}^{-2}$ ). The concentrations of surface $\mathrm{O}_{3}$ at TRF during stagnant flow regimes far exceeded those at OLY (Fig. 1d) on several days during the study, indicating $\mathrm{O}_{3}$ formation within the SMA is VOC limited, due to the overabundance of $\mathrm{NO}_{x}$ (Jeon et al., 2012, 2014). However, $\mathrm{O}_{3}$ formation can rapidly increase as the distance from $\mathrm{NO}_{x}$ sources increases. Recent chemical simulations performed during the KORUS-AQ period by Miyazaki et al. (2018) also reveal that observed boundary layer $\mathrm{O}_{3}$ can be as much as a 30 ppbv (parts per billion by volume) difference between dynamic and stagnant flow regimes. Supporting work at TRF has also shown that fast oxidation rates (Kim, 2018) and overall oxidation capacity (Jeong et al., 2018) at TRF can exacerbate severe pollution events.

The differences in daily maximum hourly $\mathrm{O}_{3}$ between the TRF and OLY sites vary from day to day, but the sites had mean and $1 \mathrm{~h}$ maximum concentrations of $86.1 \pm 21.9$ and $80.4 \pm 17.5 \mathrm{ppbv}$, respectively. The South Korean national standard for $\mathrm{O}_{3}$ is $100 \mathrm{ppbv}$ for a $1 \mathrm{~h}$ average and $60 \mathrm{ppbv}$ for an $8 \mathrm{~h}$ average (http://eng.me.go.kr/eng/web/ index.do?menuId=253, last access: 27 March 2019). Both sites exceeded the $8 \mathrm{~h}$ standard 24 times between 10 May and 10 June 2016. However, TRF exceeded the national $1 \mathrm{~h}$ standard 11 times, whereas OLY exceeded on only 3 days. These daily and diurnally varying $\mathrm{O}_{3}$ amounts during the KORUS-AQ study at TRF are described with backtrajectories (Sect. 2.1), synoptic meteorology (Sect. 2.2), and balloon-borne profiles from TRF (Sect. 3.1.1). Since the evo- 

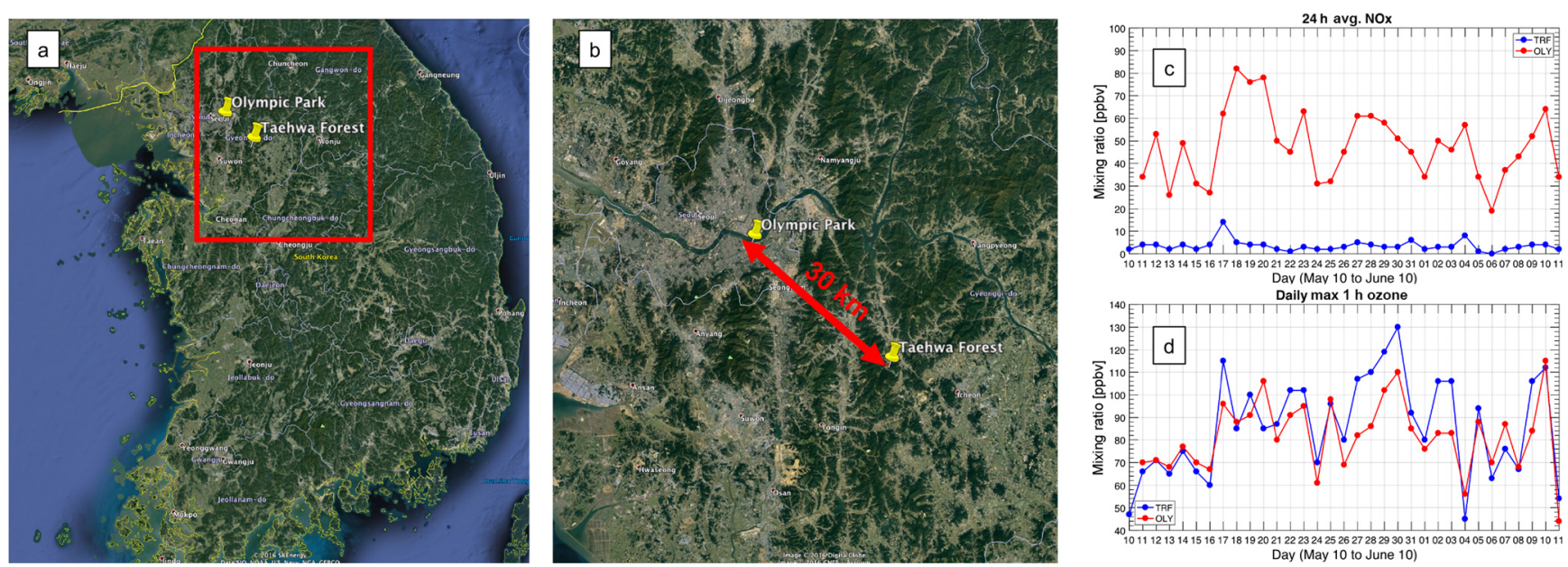

Figure 1. (a) Map of the Korean Peninsula, (b) inset view (red square from a) of the Olympic Park and Taehwa Research Forest sites, (c) daily average $\mathrm{NO}_{x}$ and (d) maximum hourly $\mathrm{O}_{3}$ at the TRF and OLY sites.

lution of plume composition is a critical component in understanding severe $\mathrm{O}_{3}$ exceedances, two contrasting case studies (17 May, Sect. 3.2, and 9 June,Sect. 3.3) of the 11 TRF $1 \mathrm{~h}$ exceedances are examined with aircraft and ground-based measurements including $\mathrm{O}_{3}$ lidar and ceilometer backscatter profiles. These are complemented by a photochemical box model used to calculate net $\mathrm{O}_{3}$ production and are used distinguish urban and industrial emissions from one of mixed urban and biogenic origins (Sect. 4).

\section{Meteorological analyses}

\subsection{Back-trajectories}

To understand variations in the air mass history as it is advected towards TRF, 4-D (time, height, latitude, longitude) back-trajectories were simulated for every day during the KORUS-AQ study (Fig. 2). The back-trajectory calculations were performed using the Lagrangian FLEXible PARTicle dispersion model (FLEXPART, http://flexpart.eu, last access: 27 March 2019; Brioude et al., 2013), driven by the WRF (Weather Research and Forecasting) model meteorology at $3 \mathrm{~km}$ spatial resolution. For this simulation, thousands of "air parcels" were released at 15:00 KST (Korean Standard Time; UTC $+9 \mathrm{~h}$ ), and their spatial and vertical (Fig. 2b) trajectory locations were followed back in time for $6 \mathrm{~h}$. Chaotic processes like turbulence or convection were applied in a stochastic manner to each parcel. At hourly intervals the concentration of parcels in each cell of a regular grid was calculated, thus providing the best statistical estimate of the air mass location and altitude prior to reaching TRF.

Red trajectory paths in Fig. 2 are used to identify air masses that were associated with the $11 \mathrm{O}_{3}$ exceedance days at TRF (based on the South Korean national standard of $1 \mathrm{~h}$ standard of $100 \mathrm{ppbv}$ in Fig. 1d). Two of these days,
17 May and 9 June (detailed in Sect. 4), are shown in yellow and orange, respectively. Conversely, days where the daily $1 \mathrm{~h} \mathrm{O}_{3}$ at TRF did not exceed $100 \mathrm{ppbv}$ are shown in blue. Days that exceeded the $1 \mathrm{~h}$ standard had generally shorter trajectory paths, indicating they were associated with more stagnant conditions and weaker synoptic forcing. The altitudes of exceedance day air masses (Fig. 2b) were also much closer to the surface (thus closer to ground level anthropogenic and biogenic emissions) as compared to nonexceedance days. Exceedance days at TRF were also associated with air masses that flowed through or near the southern portion of the SMA, where they were more likely to interact with local anthropogenic and industrial emission sources (Iqbal et al., 2014).

\subsection{Geopotential height anomalies}

The Modern-Era Retrospective analysis for Research and Applications Version 2 (MERRA-2, https://gmao.gsfc.nasa. gov/reanalysis/MERRA-2/, last access: 27 March 2019; Gelaro et al., 2017) $500 \mathrm{hPa}$ geopotential heights and anomalies (1981-2010 base period) are presented for 17 May (Fig. 3a) and 9 June 2016 (Fig. 3b) at 21:00 KST. An upperlevel ridge exists on 17 May near northeastern China as shown by positive geopotential height anomalies. Under a surface high-pressure and light synoptic forcing, winds were generally light (e.g., $1-2 \mathrm{~ms}^{-1}$ observed at TRF) and westerly in the morning and afternoon, changing to calm winds at TRF after 14:00 KST. Based on the back-trajectory (Fig. 2), the light westerly winds in the morning transported pollutants from the western portion of the SMA to the eastern portion. As the flow became more quiescent in the afternoon, local emissions were pooled in the southeastern portion of the SMA and then continued directly into the rural forested area near TRF. This synoptic system also ushered in warm (24 and $27^{\circ} \mathrm{C}$ at 15:00 KST at TRF and OLY, respectively) 


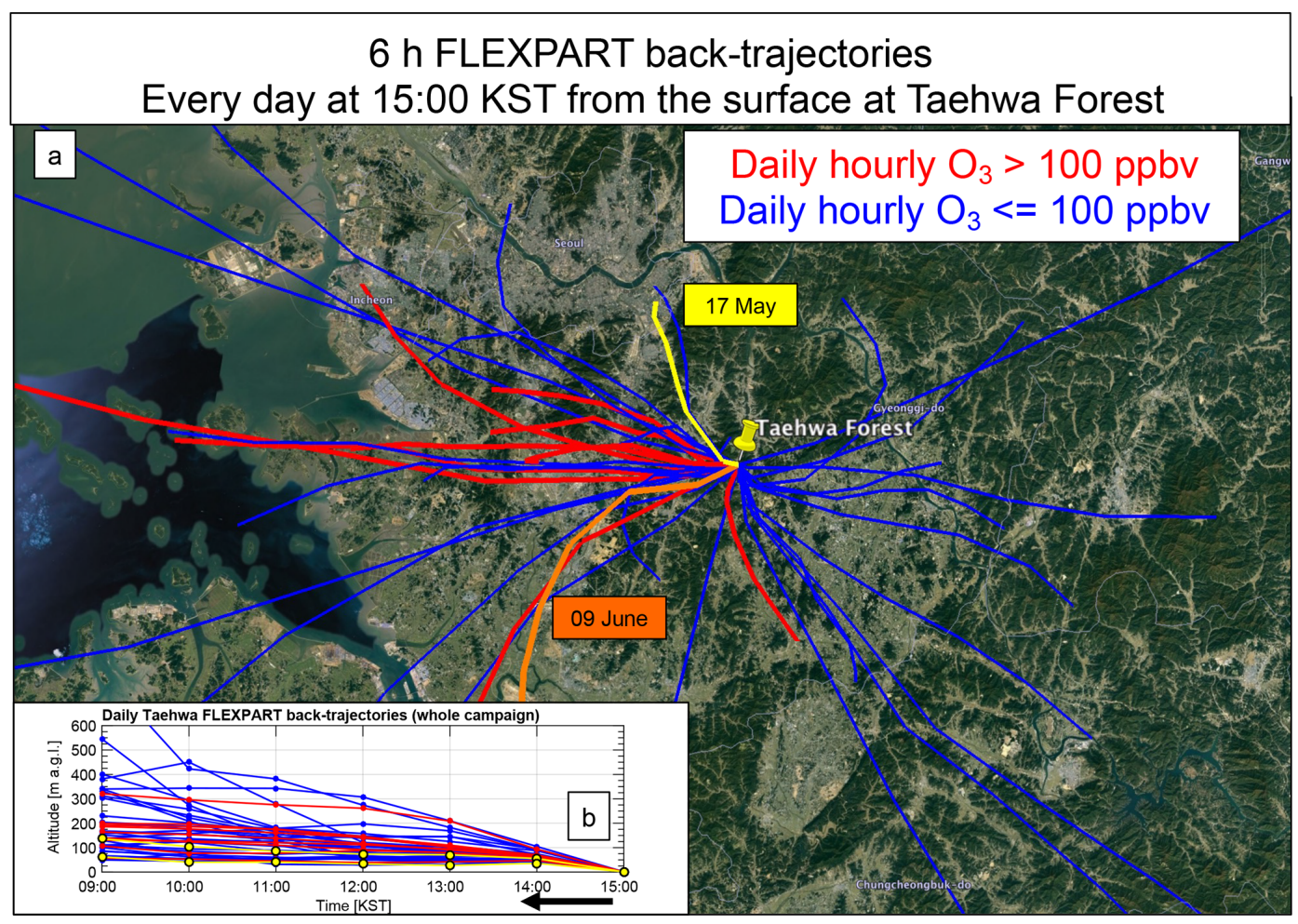

Figure 2. Daily 6h FLEXPART back-trajectory (a) spatial and (b) vertical locations for all parcels initialized at 15:00 KST at TRF throughout the KORUS-AQ campaign. The two case studies are 17 May (yellow) and 9 June (orange).

and cloud-free conditions throughout the day. With this synoptic meteorology, unimpeded solar radiation, and ample $\mathrm{O}_{3}$ precursor emissions from SMA, TRF reached a maximum hourly $\mathrm{O}_{3}$ value of nearly 120 ppbv (Fig. 1d) at 17:00 KST, well above the $100 \mathrm{ppbv}$ South Korean national standard.

In contrast, on 9 June a weak $500 \mathrm{hPa}$ ridge existed over South Korea, the Yellow Sea, and eastern China with a $+50 \mathrm{~m}$ height anomaly. Under this multi-day weak synoptic forcing, the back-trajectory indicates recirculation of the air mass throughout the Korean peninsula, rather than extended zonal transport. The air mass appears to have been tracked near Seoul on the previous day, followed by recirculation back to the densely forested region south and west of TRF. Light and northwesterly surface winds occurred in the morning and afternoon (e.g., 2-3 $\mathrm{ms}^{-1}$ at TRF), decreasing and becoming more southerly in the late afternoon (e.g., less than $0.5-1 \mathrm{~ms}^{-1}$ at TRF after 12:00 KST). Throughout the day, the light northwesterly transported pollutants from the northwest to the southeast within the SMA. As the flow reduced in the afternoon and became more southerly, local fresh (as well as aged and/or recirculated) emissions were pooled throughout the southern portion of the SMA, yielding adequate time to interact with the rural forested area near TRF. This system was also associated with much warmer $\left(27\right.$ and $31^{\circ} \mathrm{C}$ at 15:00 KST at TRF and OLY, respectively) conditions than those on 17 May, favoring increased emissions of BVOCs, such as isoprene (Kim et al., 2015). With weakly forced synoptic meteorology, TRF reached a maximum hourly $\mathrm{O}_{3}$ value of nearly $110 \mathrm{ppbv}$, exceeding the $1 \mathrm{~h} 100 \mathrm{ppbv}$ South Korean national standard.

\section{Case studies of pollution transport to TRF}

\subsection{Methods}

Vertical profiles of key atmospheric chemical constituents measured via aircraft and from ground-based platforms (Table 1) during two representative case studies are used to better understand transboundary and local transport effects from urban regions to the rural landscape. To assess the transport and evolution of urban emissions impacting TRF, airborne measurements of $\mathrm{O}_{3}, \mathrm{NO}_{2}, \mathrm{CO}$ (carbon monoxide), $\mathrm{SO}_{2}$ (sulfur dioxide), isoprene $\left(\mathrm{C}_{5} \mathrm{H}_{8}\right)$, and toluene $\left(\mathrm{C}_{6} \mathrm{H}_{5}\right.$ $\mathrm{CH}_{3}$ ) were collected. Downwind plume chemistry is also further investigated and fingerprinted using the onboard DC-8 observations and an explicitly constrained 0 -D photochemical box model simulation. Constituent profiles at TRF were also measured using ground-based instrumentation such as $\mathrm{O}_{3}$ lidar (Sullivan et al., 2016, 2017), electrochemical cell (ECC) $\mathrm{O}_{3}$ ozonesondes, and aerosol backscatter. Surface observations of $\mathrm{O}_{3}, \mathrm{NO}_{2}$, toluene, and isoprene at TRF are also presented. 

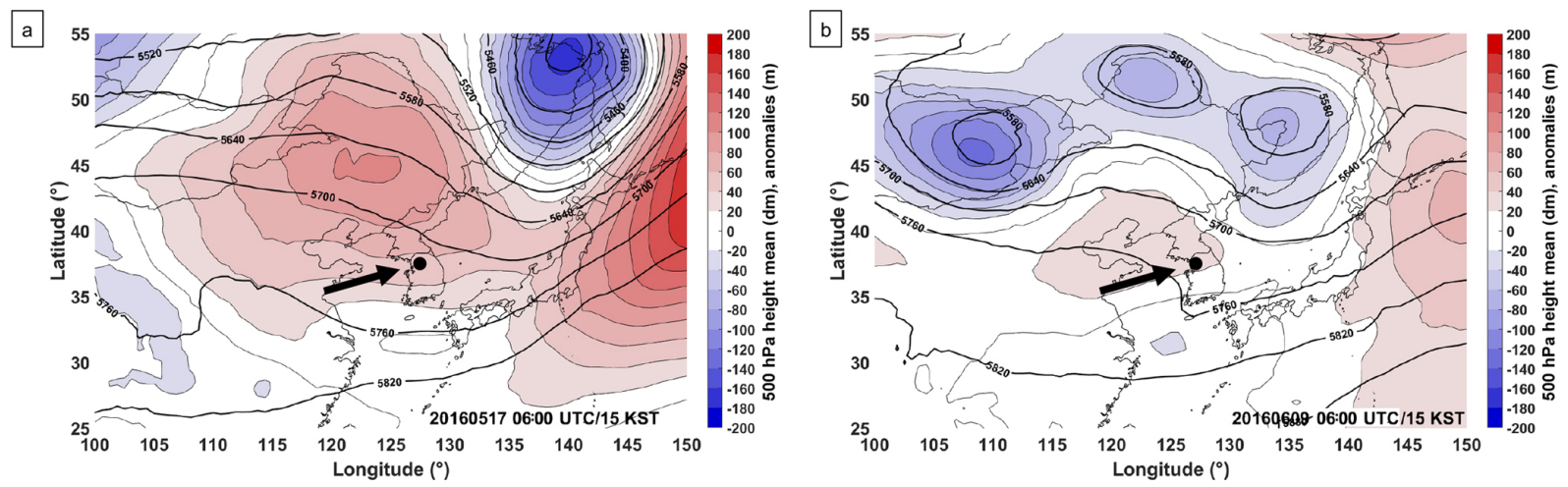

Figure 3. MERRA-2 $500 \mathrm{hPa}$ geopotential heights and anomalies for (a) 17 May and (b) 9 June 2016 at 21:00 KST (TRF marked in black dot/arrow).

Table 1. Measurement species divided by each platform used throughout the case studies.

\begin{tabular}{|c|c|c|}
\hline Quantity & Method & Reference \\
\hline \multicolumn{3}{|c|}{ Hanseo University King Air } \\
\hline $\mathrm{O}_{3}$ & UV absorption, Teledyne T400 & \multirow{4}{*}{ Kim et al. (2013) } \\
\hline $\mathrm{NO}_{2}$ & CAPS, Teledyne T500U & \\
\hline $\mathrm{CO}$ & UV fluorimetry, AeroLazer (AL5002) & \\
\hline $\mathrm{SO}_{2}$ & UV fluorimetry, Thermo $43 i$ & \\
\hline \multicolumn{3}{|l|}{ NASA DC-8 } \\
\hline $\mathrm{O}_{3} ; \mathrm{NO}_{2}$ & Chemiluminescence & Weinheimer (2006) \\
\hline Isoprene, toluene & $\begin{array}{l}\text { Proton-transfer-reaction time-of-flight } \\
\text { mass spectrometer (PTR-TOF-MS) }\end{array}$ & Müller et al. (2014) \\
\hline$P\left(\mathrm{O}_{3}\right)$ & 0-D photochemical box model & $\begin{array}{l}\text { Schroeder et al. (2016); } \\
\text { (MCM v3.3, http://mcm.leeds.ac.uk/MCM/, } \\
\text { last access: } 27 \text { March 2019) }\end{array}$ \\
\hline \multicolumn{3}{|l|}{ NASA B-200 King-Air } \\
\hline $\mathrm{NO}_{2}$ slant column & GeoTASO & Nowlan et al. (2016) \\
\hline \multicolumn{3}{|c|}{ Taehwa Research Forest (TRF) } \\
\hline $\mathrm{O}_{3}$ & Lidar, UV differential absorption & Sullivan et al. $(2014,2015 a, b)$ \\
\hline $\mathrm{O}_{3}$, temp., $\mathrm{RH}$, winds & Electro-chemical cell, balloon-borne & Thompson et al. (2007, 2019); Witte et al. (2017) \\
\hline $\mathrm{O}_{3}$ & UV absorption, Thermo 49i & $\begin{array}{l}\text { https://www.thermofisher.com/order/catalog/product/49I } \\
\text { (last access: } 27 \text { March 2019) }\end{array}$ \\
\hline $\mathrm{NO}_{2}$ & CAPS, Teledyne T500U & https://www.epa.gov/research (last access: 28 March 2019) \\
\hline Atm. backscatter & Vaisaila CL-51 & https://www.epa.gov/research (last access: 28 March 2019) \\
\hline Isoprene, toluene & $\begin{array}{l}\text { Proton-transfer-reaction mass } \\
\text { spectrometer (PTR-ToF-MS) }\end{array}$ & Kim et al. (2010) \\
\hline
\end{tabular}

The instruments aboard the NASA DC-8 and Hanseo University King Air provide accurate, fast-response measurements of trace gases and can be used in conjunction with aircraft-based remote sensing instruments in some cases to extend the characterization of pollution events. The Geostationary Trace gas and Aerosol Sensor Optimization (GeoTASO) airborne instrument was aboard the NASA B-200 King Air performing push broom raster sample routes to complement flights. Measurements of backscattered solar ra- diation are used to determine slant column (slcol) amounts of $\mathrm{NO}_{2}$ at $250 \mathrm{~m} \times 250 \mathrm{~m}$ spatial resolution, providing a quantitative spatial distribution of $\mathrm{NO}_{2}$ throughout the SMA.

\section{Ozonesonde profiles at TRF}

A total of $34 \mathrm{O}_{3}$ ozonesondes were released from TRF throughout KORUS-AQ from 10 May to 12 June. Afternoon soundings (31 of the 34 launches between 13:30 and 
16:30 KST) of $\mathrm{O}_{3}$ (Fig. 4a) and temperature (Fig. 4b) illustrate day-to-day variability in the first $3 \mathrm{~km}$ a.s.l. From 10 to 16 May, concentrations were mostly between 70 and $80 \mathrm{ppbv}$, which were associated with cooler temperatures and higher synoptic wind speeds. However, by the early afternoon of 17 May, a stagnant high-pressure system located over the Yellow Sea (see Fig. 3a) introduced a warmer air mass, calmer winds, and clearer skies. Through most of the campaign until 3 June, a similar meteorological setup persisted, providing favorable conditions for rapid $\mathrm{O}_{3}$ production to more than 120 ppbv. On 4 and 6 June, intermittent shower activity events limited $\mathrm{O}_{3}$ production. However, by 9-10 June another high-pressure system (see Fig. 3b) approached the region, increasing temperatures, suppressing wind speeds, and fostering $\mathrm{O}_{3}$ build-up. Two case studies (17 May; 9 June, black boxes) are presented in this section and Fig. 4 emphasizes the regularity of these enhanced levels of pollution.

A box-and-whisker plot of the $\mathrm{O}_{3}$ profiles binned in $500 \mathrm{~m}$ layers is also shown in Fig. 4. There were large disparities in boundary layer $\mathrm{O}_{3}$ throughout the campaign period as compared to free tropospheric conditions. Within the first $2 \mathrm{~km}$, median, lower quartile, and upper quartile ranges were 76$95,67-76$, and $87-108$ ppbv, respectively. There were no outliers within this altitude region, indicating the sondes were consistently sampling increased pollution events on flight and non-flight days during the campaign. Within the free troposphere from 2 to $6 \mathrm{~km}$, median and lower quartile $\mathrm{O}_{3}$ values were from 73 to 81 and 66 to $74 \mathrm{ppbv}$, respectively. This is markedly larger than the $50-65$ ppbv baseline $\mathrm{O}_{3}$ estimates derived for Trinidad Head, CA; Boulder, CO; and Huntsville, AL, USA (Stauffer et al., 2016; Kuang et al., 2017). This highlights the infrequency (i.e., $<25 \%$ of the time) of measuring less than $66 \mathrm{ppbv}$ of $\mathrm{O}_{3}$ within the boundary layer and free troposphere and the subsequent regulatory challenge of meeting the $8 \mathrm{~h}$ Korean $\mathrm{O}_{3}$ standard (60 ppbv).

\subsection{Pollution event: 17 May 2016}

\subsubsection{Aircraft analyses: Hanseo University King Air}

The positioning of the large-scale ridge displayed in Fig. 3a was favorable for transport of Chinese industrial (e.g., CO; $\mathrm{SO}_{2}$ ) and urban emissions to the Korean peninsula (Lee et al., 2008). To assess potential transboundary transport from other East Asian megacities, trajectories are shown for a full $48 \mathrm{~h}$ prior to reaching TRF at 17 May at 15:00 KST. The $48 \mathrm{~h}$ back-trajectory (top panel, Fig. 5) indicates the air mass was transported over the eastern China province of Shangdong, the Yellow Sea, and SMA prior to reaching TRF. Pollution entering South Korea via this pathway was measured by NIER instruments (Table 1) aboard the Hanseo University King Air aircraft during the morning of 17 May 2016 (Fig. 5).
The Hanseo University King Air conducted a sampling pattern that included a near-ground-level approach in Seoul and westbound leg out towards the Yellow Sea (green panel, Fig. 5), a southbound leg directly over the Yellow Sea at two altitudes (orange panel, Fig. 5), a returning eastbound leg (magenta panel, Fig. 5), and then finally a northbound returning leg towards Seoul (cyan panel, Fig. 5). During this pattern, measurements of $\mathrm{O}_{3}, \mathrm{NO}_{2}, \mathrm{CO}$, and $\mathrm{SO}_{2}$ capture long-range pollution transport across the Yellow Sea. Eastern China is densely populated with coal-fired power plants, which are strong emitters of $\mathrm{NO}_{x}, \mathrm{SO}_{2}$, and particulate matter (Zhao et al., 2008). Carbon monoxide and $\mathrm{SO}_{2}$ are longer lived species with lifetimes on the order of 1-2 months (Miyakazi et al., 2012) and 1-2 days (He et al., 2012), respectively, and are used to support the interpretation of transboundary pollution transport. During the KORUS-AQ study period, Huang et al. (2018) has further used CO to evaluate chemical transport models and assess transboundary impacts on the Korean peninsula.

During the low-level approach to Seoul near 08:55 KST (denoted with dashed black line, Fig. 5) chemical sampling of low $\mathrm{O}_{3}$ (20-40 ppbv), high $\mathrm{NO}_{2}$ (20-40 ppbv), high $\mathrm{CO}$ concentrations (500-700 ppbv), and high $\mathrm{SO}_{2}$ (6-10 ppbv) are observed in the first $500 \mathrm{~m}$ a.s.l. These indicate morning urban emissions (and subsequent $\mathrm{O}_{3}$ titration) and because of the proximity to the surface level, these pollutants are largely associated with local SMA vehicular and industrial morning emissions. As the aircraft moves westward at $1000 \mathrm{~m}$ a.s.l., it samples a much cleaner air mass but reaches a plume of polluted air near 09:20 KST, associated with increased concentrations of $\mathrm{O}_{3}$ (to $90 \mathrm{ppbv}$ ), $\mathrm{CO}$ (to $500-600 \mathrm{ppbv}$ ), and $\mathrm{SO}_{2}$ (to 6-8 ppbv). In conjunction with the $48 \mathrm{~h}$ back-trajectory, this is likely the outflow of aged industrial emission from eastern China (Zhao et al., 2008) that has been transported over the Yellow Sea. Similar concentrations of these species are observed during the southbound leg at $500 \mathrm{~m}$ a.s.l., indicating that the vertical distribution of pollutants is relatively well mixed in the polluted air mass from 500 to $1000 \mathrm{~m}$ a.s.l. During the eastbound leg at $1500 \mathrm{~m}$ a.s.l., the aircraft samples mostly clean air with the exception of a pollution plume at 10:55 KST. As the aircraft returns to the Korean peninsula, it observes relatively cleaner conditions until it approaches the southern portion of the SMA near 11:30 KST.

In summary, the westbound in situ observations indicate transport of polluted air across the Yellow Sea towards South Korea. The largest chemical perturbations (e.g., 15-40 ppbv in $\mathrm{NO}_{2} ; 6-10 \mathrm{ppbv}$ in $\mathrm{SO}_{2}, 200-300 \mathrm{ppbv}$ in $\mathrm{CO}$ ) during the flight pattern were spatially correlated with local emission sources during the initial ground level approach and the final transect nearing the SMA. The southbound transect indicated on this day that the background level of $\mathrm{O}_{3}$ is near $60 \mathrm{ppbv}$ and a 20-30 ppbv enhancement in $\mathrm{O}_{3}$ is observed at $500 \mathrm{~m}$ over the water. However, the increases in $\mathrm{NO}_{2}$ are chemically responsible for rapid $\mathrm{O}_{3}$ production, which were observed in near-negligible amounts during the transboundary transects. 

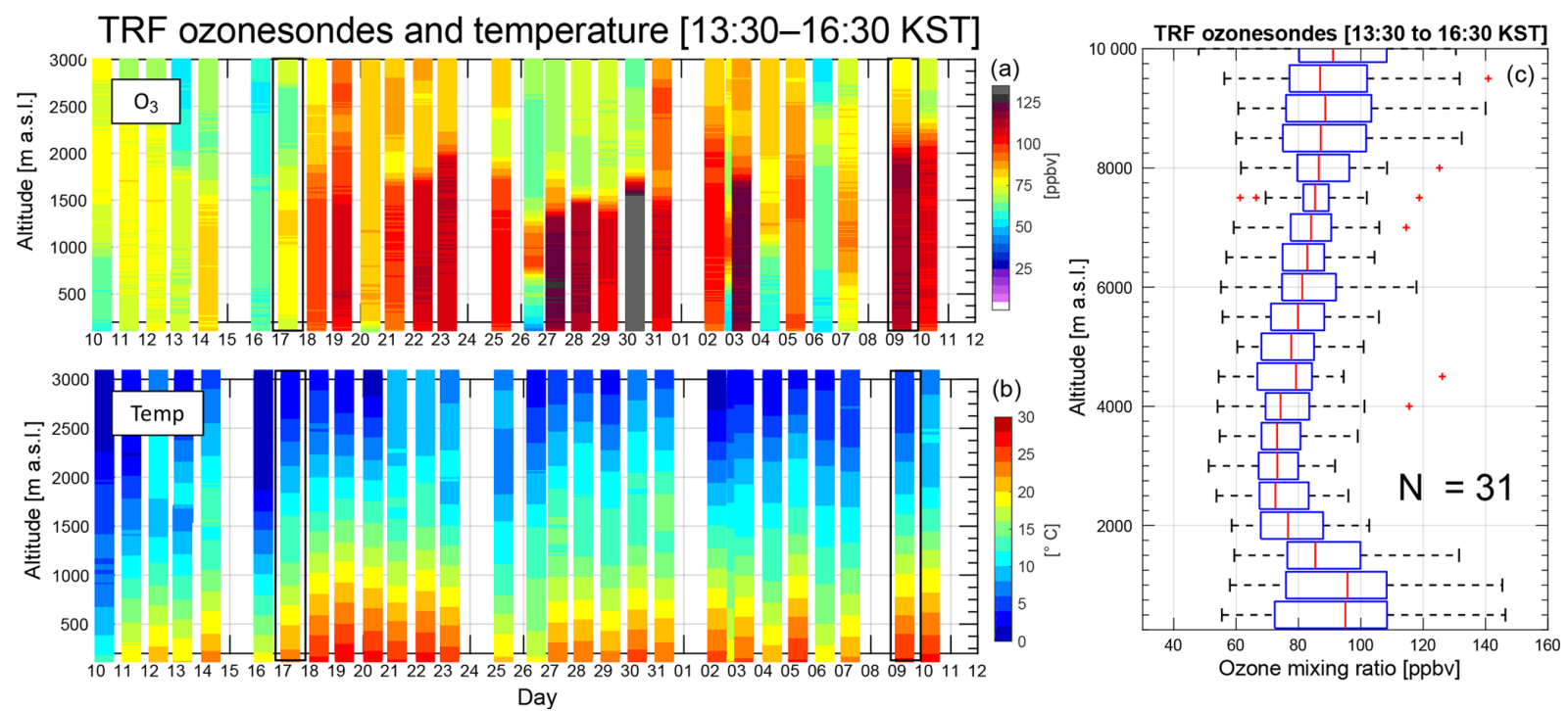

Figure 4. Afternoon soundings (13:30 to $16: 30 \mathrm{KST}$ ) of $\mathrm{O}_{3}$ (a, from ECC $\mathrm{O}_{3}$ ozonesondes) and temperature (b, from concurrent radiosondes) and a box-and-whisker plot (c) illustrate day-to-day variability at TRF. The two case studies (17 May and 9 June) are highlighted with black boxes.

\subsubsection{Aircraft analyses: NASA DC-8}

Chemical observations from the NASA DC-8 throughout the SMA from 15:05 to 15:40 KST on 17 May 2016 are presented (Fig. 6). The aircraft route (Fig. 6a, with arrows) begins in the southern region at $2.1 \mathrm{~km}$ a.s.l., moving northwards towards TRF and descending to near $1.7 \mathrm{~km}$ a.s.l. The aircraft maintains this altitude on a northward track and turns westward and descends to near $1.0 \mathrm{~km}$ a.s.l. towards Seoul to perform a near-ground-level pass near the Seoul Incheon airport. The aircraft continues at $1.0 \mathrm{~km}$ a.s.l., overpasses TRF near $0.5 \mathrm{~km}$ a.s.1., descends to nearly $0.3 \mathrm{~km}$ a.s.1., and then quickly ascends out of the boundary layer. The constituents shown from the flight path are $\mathrm{O}_{3}$ (Fig. 6b), $\mathrm{NO}_{2}$ (Fig. 6c), isoprene (Fig. 6d), toluene (Fig. 6e), and $\mathrm{O}_{3}$ production $\left(P\left(\mathrm{O}_{3}\right)\right.$, Fig. 6f).

Toluene, a reactive aromatic and industrial VOC, is a useful tracer for urban anthropogenic emissions because it is a highly reactive $\mathrm{O}_{3}$ precursor with a chemical lifetime on the order of a day. Toluene is a dominant VOC throughout the SMA and contributes to nearly $60.7 \%$ of the total VOC emissions (Lee et al., 2011). Isoprene, a BVOC and derivative of photosynthesis, is largely associated with deciduous trees (e.g., oak, which accounts for $85 \%$ of broadleaf trees in South Korea; Lim et al., 2011). Isoprene can enhance photochemical $\mathrm{O}_{3}$ production, is emitted almost entirely during the daytime, can form additional oxidative byproducts, and is released more abundantly with increased temperatures. Previous results from Kim et al. (2015) indicate that isoprene accounts for most of the midday hydroxyl radical $(\mathrm{OH})$ reactivity (11:00-15:00 KST) at TRF and can rapidly increase $\mathrm{O}_{3}$ production rates.
Within the SMA and below $0.5 \mathrm{~km}$ a.s.l., there is a significant chemical perturbation as compared to the free tropospheric concentrations of $\mathrm{NO}_{2}(40-50$ ppbv, Fig. 6c) and toluene (5-7 ppbv, Fig. 6e). These increases both lead to increases in modeled $P\left(\mathrm{O}_{3}\right)\left(10-20 \mathrm{ppbvh}^{-1}\right.$, Fig. 6f). Isoprene is mostly less than $0.3 \mathrm{ppbv}$ during this sampling. The concentrations of $\mathrm{NO}_{2}$ have increased by $10-20 \mathrm{ppbv}$ since the afternoon Hanseo University King Air sampling (Fig. 5), indicating a persistent reservoir of reactive nitrogen coming from SMA throughout the day. Additional DC-8 observations (not shown) indicate $\mathrm{NO}_{2}$ accounted for $70 \%-$ $90 \%$ of the total reactive nitrogen during the 17 May overpass at TRF. Ozone remains mostly between 70 and $80 \mathrm{ppbv}$ (Fig. 6b) during the initial descent into Seoul, indicating emissions are fresh enough that rapid $\mathrm{O}_{3}$ production has not occurred yet (which is further corroborated with the $P\left(\mathrm{O}_{3}\right)$ model output).

As the aircraft moves towards TRF, it samples various spatial chemical gradients. For example, $\mathrm{NO}_{2}$ and toluene concentrations decrease to near $20-30$ ppbv and near $2-3 \mathrm{ppbv}$, respectively. An increase in isoprene concentrations to 0.5$0.8 \mathrm{ppbv}$ corresponds to the forested region southeast of Seoul. Directly over TRF, $\mathrm{O}_{3}$ concentrations are increased as compared to those near Seoul by $5-10 \mathrm{ppbv}$, indicating that downwind $\mathrm{O}_{3}$ production has increased with diluted levels of $\mathrm{NO}_{x}$. The aircraft passes TRF and continues its eastward descent to $0.3 \mathrm{~km}$ a.s.l.; $\mathrm{O}_{3}$ concentrations markedly increase to between 110 and $125 \mathrm{ppbv}$ and $P\left(\mathrm{O}_{3}\right)$ rapidly increases to between 20 and $32 \mathrm{ppbv} \mathrm{h}^{-1}$. Although the aircraft samples nearly negligible concentrations of isoprene and $\mathrm{NO}_{2}$, toluene concentrations have increased and are comparable to those sampled near Seoul (3-4 ppbv). This is a strong indica- 


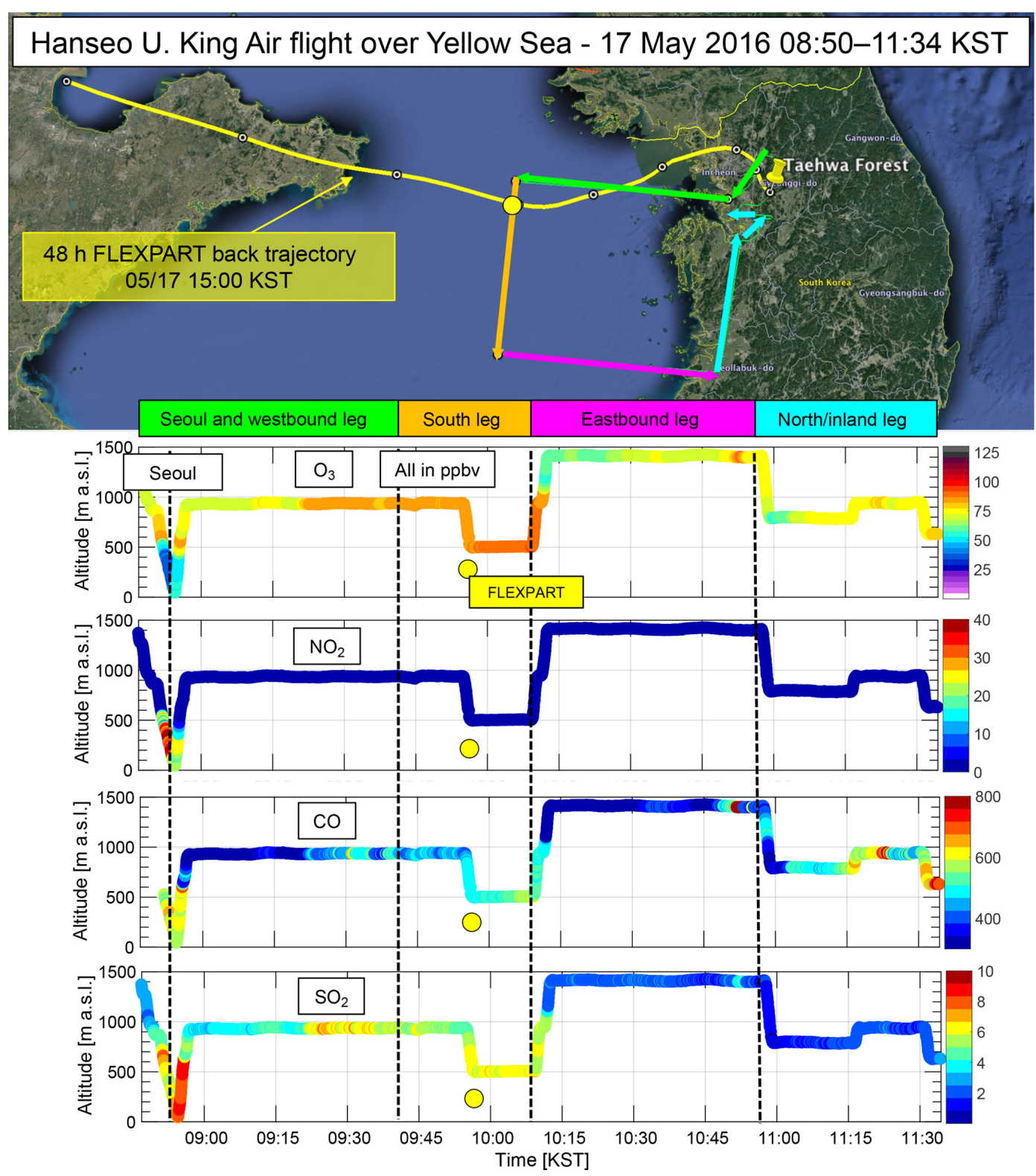

Figure 5. Hanseo University King Air Flight on 17 May 2016 to sample $\mathrm{O}_{3}, \mathrm{NO}_{2}, \mathrm{CO}$, and $\mathrm{SO}_{2}$ over South Korea and the Yellow Sea from 08:50 to 11:34 KST. The $48 \mathrm{~h}$ FLEX-PART back-trajectory, which was initialized at 15:00 KST on 17 May 2016, is also shown.

tor of an aged urban air mass containing highly reactive $\mathrm{O}_{3}$ precursors impacting rural sites. In summary, transboundary pollution transport was observed via the Hanseo University King Air (Fig. 5) on 17 May, but locally emitted $\mathrm{O}_{3}$ precursors can be confidently attributed as a catalyst for the highest levels of boundary layer $\mathrm{O}_{3}$ production observed near TRF.

\subsubsection{Ground-based observations at TRF}

To fingerprint and quantify the transported pollution reaching TRF, diurnally resolved observations are presented in Fig. 7 for the entirety of 17 May.
08:00 to 12:00 KST. Ceilometer observations (Fig. 7a) and GSFC $\mathrm{O}_{3}$ lidar observations (Fig. 7b), both containing an aerosol mixing height retrieval (black line), indicate residual layers and vertical stratification. Above the boundary layer between 1000 and $1700 \mathrm{~m}$ a.s.l., enhanced aerosol backscatter and concentrations of $\mathrm{O}_{3}$ near $70-80 \mathrm{ppbv}$ are similar in concentration and altitude to the transboundary pollution observed during the morning Hanseo University aircraft flight (Fig. 5). Atmospheric layering also exists below 850 m a.s.l., with a distinct high $\mathrm{O}_{3}(100-120 \mathrm{ppbv})$ region near $600 \mathrm{~m}$ a.s.l. and low $\mathrm{O}_{3}(20-40 \mathrm{ppbv})$ and high aerosol backscatter from 600 to $850 \mathrm{~m}$ a.s.l. Although $\mathrm{NO}_{2}$ concen- 


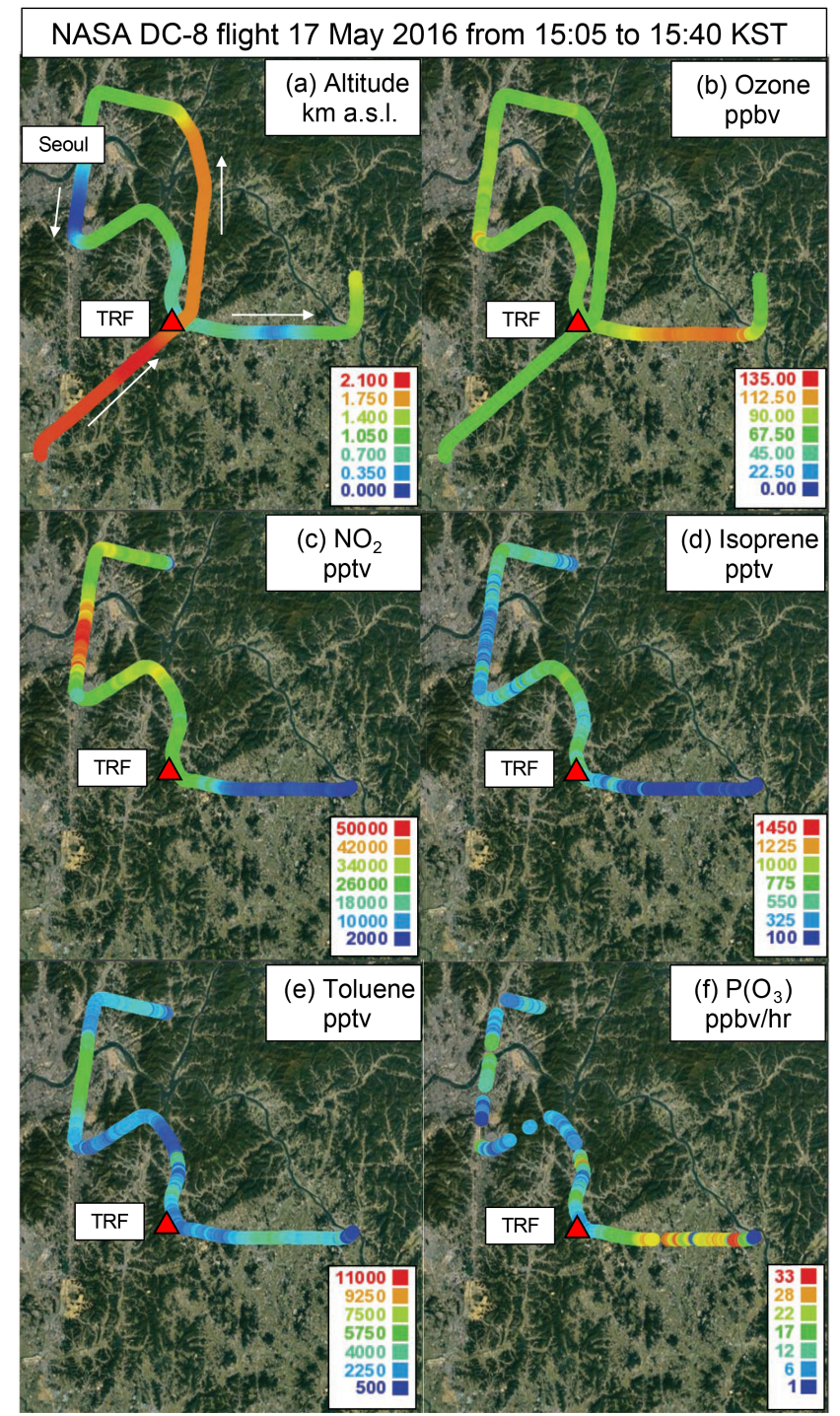

Figure 6. NASA DC-8 measurements of (a) altitude, (b) $\mathrm{O}_{3}$, (c) $\mathrm{NO}_{2}$, (d) isoprene, (e) toluene, and (f) modeled $P\left(\mathrm{O}_{3}\right)$ from the afternoon science flight on 17 May 2016 from 15:05 to 15:40 KST. Seoul and TRF are denoted.

trations are enhanced from 5 to 15 ppbv during this segment, near 09:00 KST, residual layer entrainment appears to occur as surface $\mathrm{O}_{3}$ (Fig. 7c) abruptly increases from 40 to $60 \mathrm{ppbv}$. Increases in nitrate aerosol, either through $\mathrm{N}_{2} \mathrm{O}_{5}$ hydrolysis or morning residual layer entrainment, within the SMA during the KORUS-AQ study have been further examined by Kim et al. (2018). Near 11:30 KST, toluene (Fig. 7d) levels increase to peak values for the day, near 8-9 ppbv, indicating the transport of urban industrial emissions (including the increased $\mathrm{NO}_{2}$ ) to the site is well underway.

12:00 to 19:00 KST. The boundary layer is convectively well-mixed to $1200 \mathrm{~m}$ a.s.l. with $\mathrm{O}_{3}$ concentrations near 85$95 \mathrm{ppbv}$, similar to the in situ surface monitor. This plume has similar chemical composition to the plume observed "downwind", or east, of TRF in the DC-8 observations, indicating $\mathrm{O}_{3}$ production continued as it moved away from the SMA. $\mathrm{O}_{3}$ concentrations begin to decrease (by $25 \mathrm{ppbv}$ ) near 14:00 KST, in conjunction with a 25 ppbv increase in $\mathrm{NO}_{2}$, conserving total odd oxygen $\left(\mathrm{O}_{x}\right)$. Near 15:20 KST, the DC-8 overflew TRF and sampled comparable concentrations of $\mathrm{O}_{3}$ and $\mathrm{NO}_{2}$ as the lidar, sonde, and surface measurements. As emissions continue to photochemically process and advect over the TRF site, there is a rapid increase in $\mathrm{O}_{3}$, well-mixed throughout the boundary layer, at TRF between 16:00 and 17:00 KST. Ozone concentrations increase by $60 \mathrm{ppbv}$ and $\mathrm{NO}_{2}$ decreases by $15 \mathrm{ppbv}$, indicating total $\mathrm{O}_{x}$ is not conserved and a passing plume of urban emissions has arrived at TRF. Isoprene (Fig. 7d) does not show a rapid change throughout the day; however, it is near peak concentration during this time. Concentrations of $\mathrm{O}_{3}$ above 125 ppbv persist until 18:30 KST, although the mixing height decreases rapidly during this time. The in situ observations indicate concentrations were above $100 \mathrm{ppbv}$ until 18:30, indicating polluted conditions persisted well into the evening at the surface and even longer aloft. This later afternoon buildup and transport is also identified with results from Lennartson et al. (2018) during the KORUS-AQ study, which indicate TRF had consistently higher aerosol optical depth (AOD) values of near 0.4-0.6 in the morning, decreasing throughout the day and eventually rising again in the early evening at 15:0016:00 KST.

19:00-23:00 KST. After sunset (near 19:00 KST), increases in aerosol backscatter and $\mathrm{O}_{3}$ near $1500 \mathrm{~m}$ a.s.l. are observed, indicating a stable residual layer persisted into the evening, trapping pollutants at TRF. As surface $\mathrm{O}_{3}$ quickly decayed to near $20 \mathrm{ppbv}$ after 19:00 KST, it corresponded to increases in $\mathrm{NO}_{2}$ from near 15 to $20-30 \mathrm{ppbv}$ and toluene from 2 to $4 \mathrm{ppbv}$, which corroborate the incoming pollution plume quantified with the DC-8 observations (Fig. 6c, e). This indicates TRF was continuously perturbed by local urban emissions into the evening hours and this has likely affected the next day's chemical composition (e.g., Fig. 4 indicates $\mathrm{O}_{3}$ at TRF on 18 May exceeded $>100 \mathrm{ppbv}$ ). Although the combined suite of aircraft (Fig. 5) and lidar and ceilometer observations (Fig. 7a, b) suggest transboundary $\mathrm{O}_{3}$ and pollutants reached the TRF site, the lidar and in situ observations clearly indicate domestic anthropogenic emissions were the dominant source of the $\mathrm{O}_{3}$ exceedance at TRF.

\subsection{Pollution event: 9 June 2016}

\subsubsection{Aircraft analyses: NASA DC-8}

Chemical observations were made with the NASA DC-8 instruments in a similar pattern to those on 17 May 2016 throughout the SMA from $15: 20$ to $15: 55 \mathrm{KST}$ on 9 June 2016 (Fig. 8a, with arrows). However, the aircraft remained at lower altitudes during the flight pattern prior to 
TRF remotely sensed and in situ measurements 17 May 2016
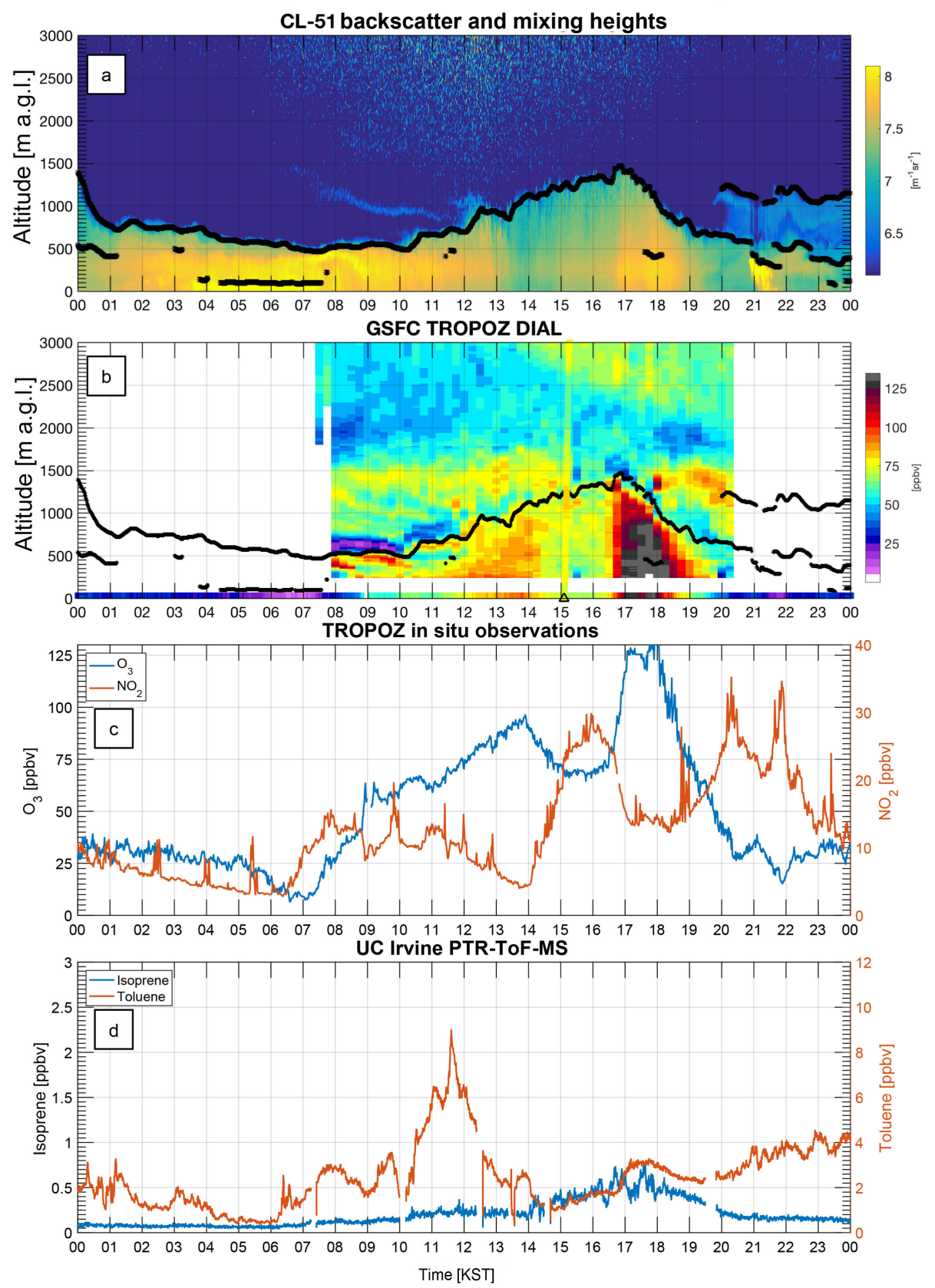

Figure 7. Time series of (a) ceilometer backscatter profiles and mixing heights, (b) GSFC TROPOZ DIAL $\mathrm{O}_{3}$ profiles, (c) in situ surface $\mathrm{O}_{3}$ and $\mathrm{NO}_{2}$, and (d) isoprene and toluene concentrations for 17 May 2016. Note: the DC-8 overpass occurred at around 15:30 KST. The colocated ozonesonde is denoted in (b) with a black triangle.

the initial upper-level pass of TRF. This resulted in low-level sampling of the forested region and recirculated air mass. This aged air mass was associated with increased concentrations of $\mathrm{O}_{3}$ to over $120 \mathrm{ppbv}$ (Fig. 8b), low concentrations of $\mathrm{NO}_{2}$ (less than 5 ppbv; Fig. 8c), variable concentrations of toluene (between 5 and 10 ppbv; Fig. 8e), variable concentrations of isoprene (between 0.1 and 0.7 ppbv; Fig. 8d), and $P\left(\mathrm{O}_{3}\right)$ values between 20 and $35 \mathrm{ppbv} \mathrm{h}^{-1}$ (Fig. 8f).
As the aircraft ascended out of the boundary layer prior to reaching Seoul, $\mathrm{O}_{3}$ remained above $100 \mathrm{ppbv}$ near $2000 \mathrm{~m}$ a.s.l. Mixing heights are $500 \mathrm{~m}$ deeper than on 17 May, presumably as a result of warmer temperatures and greater convective mixing. As the DC- 8 ascended out of the overpass south of Seoul, $\mathrm{NO}_{2}$ concentrations reached 20 $30 \mathrm{ppbv}$, toluene reached 3-6 ppbv, and isoprene exceeded $1.2 \mathrm{ppbv}$ (nearing the peak concentration measured via the 


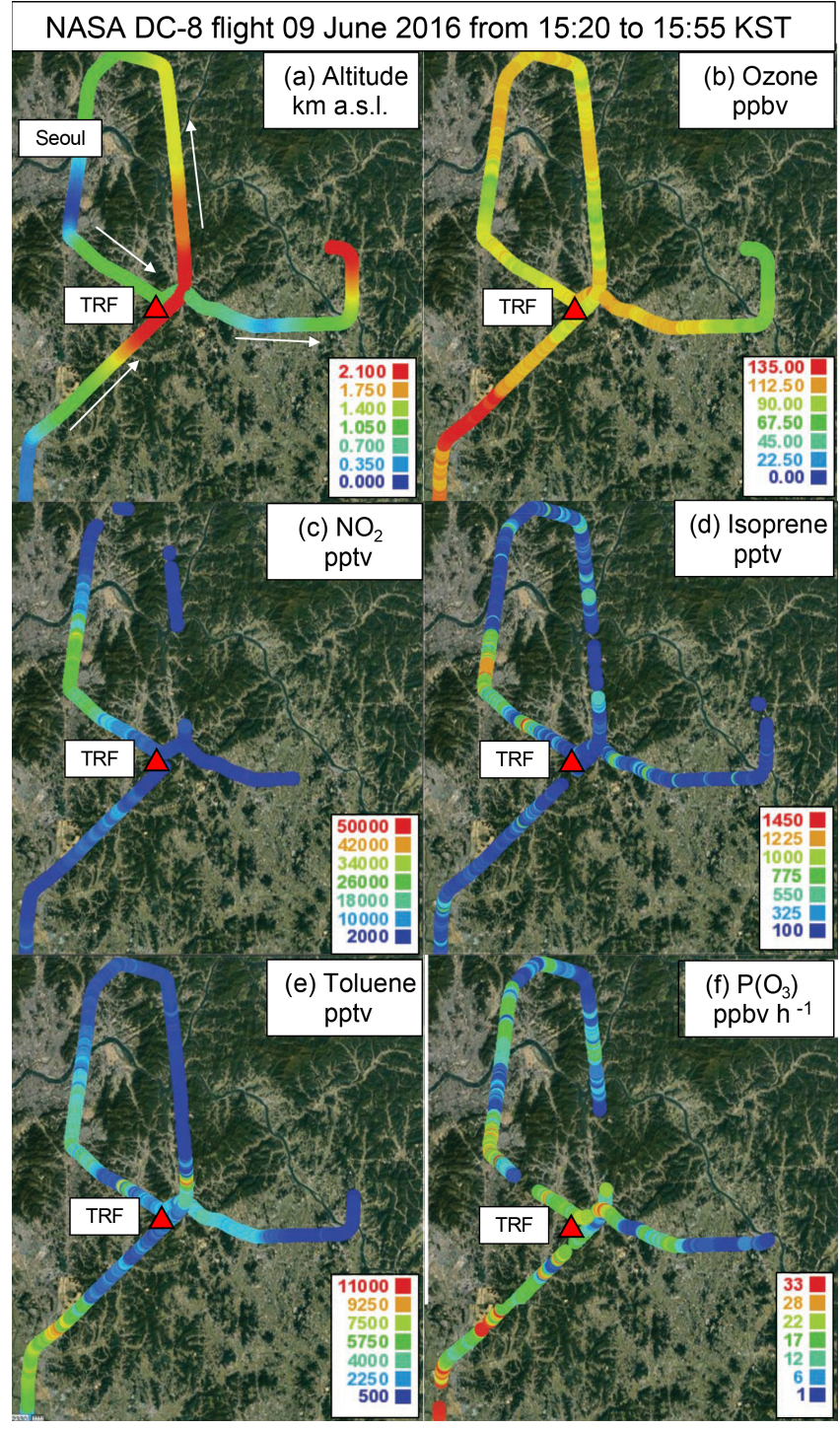

Figure 8. NASA DC-8 measurements of (a) altitude, (b) $\mathrm{O}_{3}$, (c) $\mathrm{NO}_{2}$, (d) isoprene, (e) toluene, and (f) modeled $P\left(\mathrm{O}_{3}\right)$ from the afternoon science flight on 17 May 2016 from 15:05 to 15:40 KST.

DC-8 during the entire campaign). This air mass was also associated with lower values of $\mathrm{O}_{3}$ and $P\left(\mathrm{O}_{3}\right)$ as compared to the forest plume south of TRF, at $75-90 \mathrm{ppbv}$ and 10 $20 \mathrm{ppbvh}^{-1}$, respectively, indicating the anthropogenic and biogenic emissions were still fresh. Similar to 17 May, as the aircraft leaves urban Seoul and approaches TRF there is a strong spatial gradient in nearly all chemical constituents. At TRF, $\mathrm{O}_{3}$ and $P\left(\mathrm{O}_{3}\right)$ increase to over $120 \mathrm{ppbv}$ and $30 \mathrm{ppbvh}^{-1}$, respectively, while $\mathrm{NO}_{2}$ decreases to 5$10 \mathrm{ppbv}$, indicating $\mathrm{O}_{3}$ production was rapidly occurring and impacting rural sites downwind of Seoul.

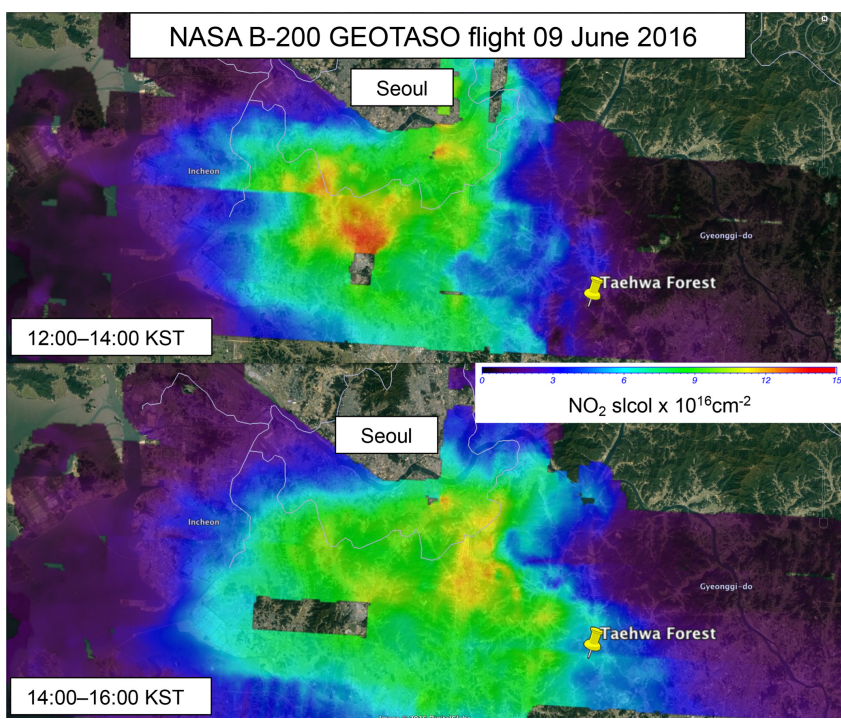

Figure 9. Observations of $\mathrm{NO}_{2}$ slant columns from the GeoTASO instrument during the two afternoon science flights on 9 June 2016 from $12: 00$ to $14: 00$ and $14: 00$ to $16: 00 \mathrm{KST}$. TRF and Seoul are denoted.

\subsubsection{Aircraft analyses: NASA B-200}

On 9 June 2016, the NASA B-200 performed a morning and afternoon raster (Fig. 9) of the greater SMA from 12:00 to 14:00 and 14:00 to 16:00 KST, respectively. This yields a unique view of the concentrations and chemical transport of $\mathrm{NO}_{2}$ throughout the SMA during the afternoon hours. During the 12:00-14:00 KST sampling, there is a clear maximum in $\mathrm{NO}_{2}$ slant columns in the south and west of Seoul. Afterwards, the 14:00-16:00 KST measurements show the advection of $\mathrm{NO}_{2}$ (and presumably other urban pollutants) eastward and southward throughout the SMA. During the 14:0016:00 flight, large $\mathrm{NO}_{2}$ column amounts extend to the southeastern portion of the SMA, with enhanced levels of $\mathrm{NO}_{2}$ reaching the edge of TRF.

\subsubsection{Ground-based observations at TRF}

To fingerprint and quantify the chemical transport reaching TRF, diurnally resolved observations are presented in Fig. 10 for the entirety of 9 June.

08:00 to 12:00 KST. Similar to 17 May, vertical profiles of aerosol backscatter and $\mathrm{O}_{3}$ (Fig. 10a, b) throughout 9 June indicate residual layering of the atmosphere in the morning hours. There exist descending layers of aerosols above the residual layer associated with the recirculation of the air mass from the previous day. Near 09:00 KST entrainment of the residual $\mathrm{O}_{3}$ corresponds to an abrupt surface $\mathrm{O}_{3}$ increase from 20 to $55 \mathrm{ppbv}$ (Fig. 10c). TRF is impacted with increased surface $\mathrm{NO}_{2}$ (Fig. 10c) towards $30 \mathrm{ppbv}$ and toluene (Fig. 10d) towards 4 ppbv during this time. Warmer temper- 
TRF remotely sensed and in situ measurements 09 June 2016
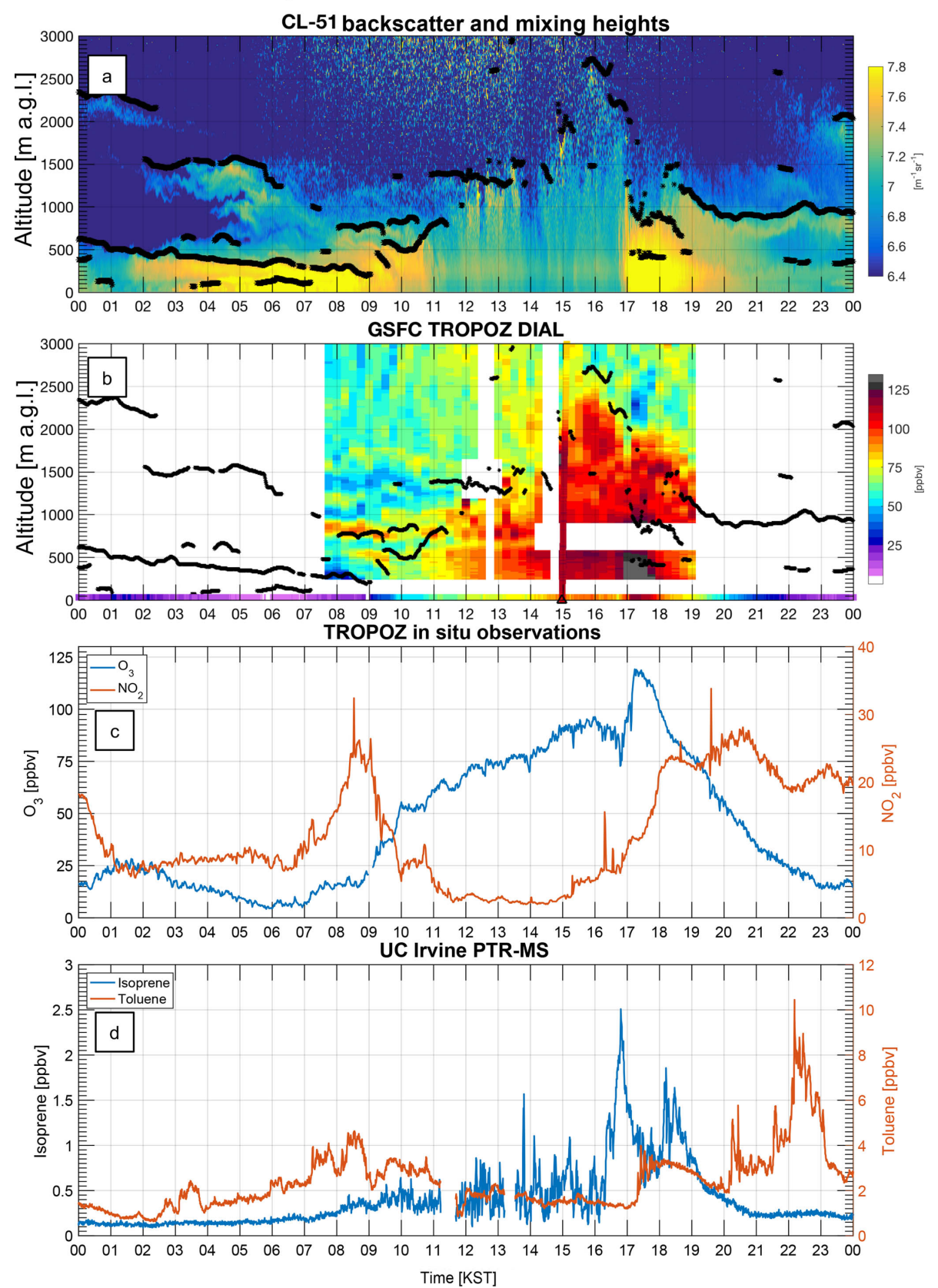

Figure 10. Time series of (a) ceilometer backscatter profiles and mixing heights, (b) GSFC TROPOZ DIAL $\mathrm{O}_{3}$ profiles, (c) in situ surface $\mathrm{O}_{3}$ and $\mathrm{NO}_{2}$, and (d) isoprene and toluene concentrations for 9 June 2016. Note: the DC-8 overpass occurred near 15:30 KST. The colocated ozonesonde is denoted in (b) with a black triangle.

atures on 9 June compared to 17 May lead to higher daytime isoprene concentrations ( 0.5 vs. $0.3 \mathrm{ppbv}$ ).

12:00 to 19:00 KST. Boundary layer concentrations of $\mathrm{O}_{3}$ and aerosols are well mixed with steady growth in $\mathrm{O}_{3}$ from 12:00 until 16:30 KST, when a rapid influx of $\mathrm{O}_{3}$ and aerosol occurs. This occurs after a significant positive perturbation in isoprene and precedes an abrupt increase in $\mathrm{NO}_{2}$ and toluene. The $\mathrm{O}_{3}$ peak closely corresponds to the $\mathrm{O}_{3}$ sampled via the
DC-8 south and west of TRF, and in conjunction with the back-trajectory (Fig. 2), it appears $\mathrm{O}_{3}$ was likely advected through TRF during this time.

19:00 to 23:00 KST. As solar radiation declines, in-air concentrations of $\mathrm{O}_{3}$ near $100 \mathrm{ppbv}$ mixing to $2000 \mathrm{~m}$ a.s.l. are observed, indicating a stable residual layer persisted into the evening and likely impacted the next day's $\mathrm{O}_{3}$ composition (e.g., Fig. 4 indicates $\mathrm{O}_{3}$ at TRF on 10 June ex- 

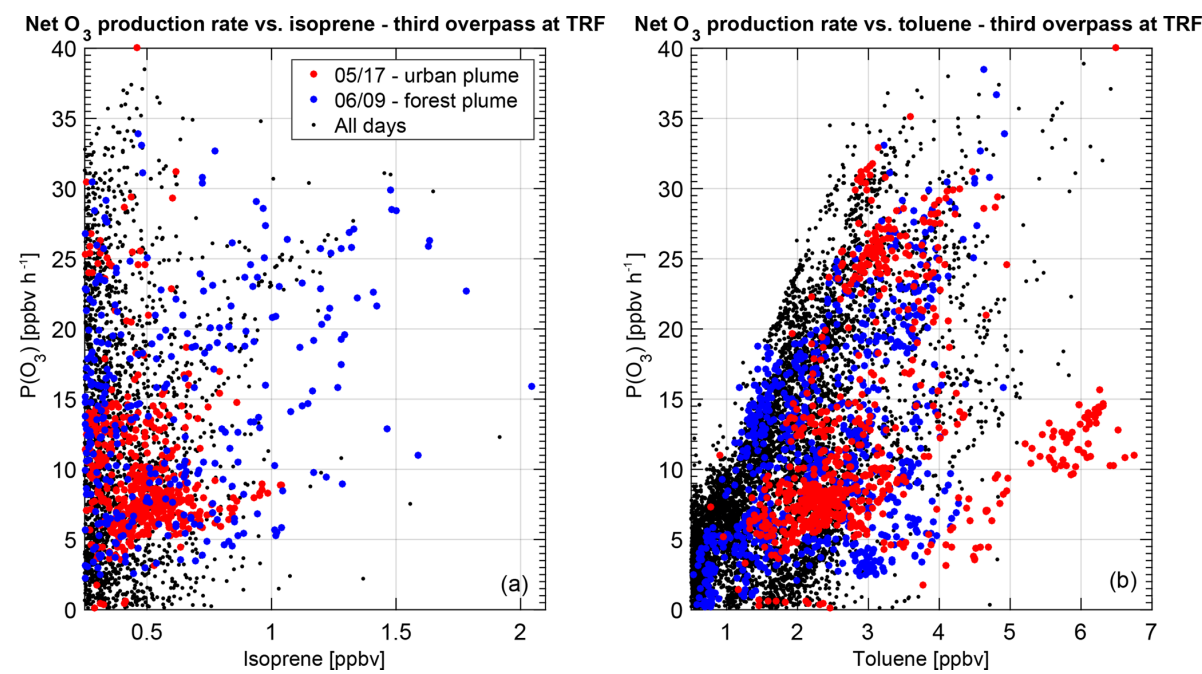

Figure 11. Photochemical model output of net $\mathrm{O}_{3}$ production, $P\left(\mathrm{O}_{3}\right)$, for all afternoon flights during the KORUS-AQ study compared to measured concentrations of isoprene (a) and toluene (b). The case studies described in Sect. 3 are denoted in red (17 May 2016) and blue (9 June 2016).

ceeded $>100 \mathrm{ppbv}$ ). As surface $\mathrm{O}_{3}$ quickly decayed to near $20 \mathrm{ppbv}$ after 19:00 KST, it corresponded to increases in $\mathrm{NO}_{2}$ from near 15 to $20-30 \mathrm{ppbv}$ and toluene from 8 to $10 \mathrm{ppbv}$, which points to the incoming pollution plume captured with the GeoTASO observations (bottom panel, Fig. 9), indicating TRF was impacted by regional urban emissions into the evening hours. In conjunction with the aircraft, lidar, and surface in situ observations, this case study emphasizes the role of domestically produced emissions (both biogenic and anthropogenic) in perturbing the chemical composition downwind of Seoul.

\section{Case studies in the context of the entire KORUS-AQ study}

\subsection{Aircraft observation and $P\left(\mathrm{O}_{3}\right)$}

Although two case studies are presented to illustrate the contrasting types of pollution influences at TRF, it is important to assess how representative events were for the entire KORUS-AQ study. To do this, the chemical observations of isoprene (Fig. 11a) and toluene (Fig. 11b) aboard the NASA DC-8 are presented for all remaining afternoon flights (exact dates can be found here: http://www-air.larc.nasa.gov/ missions/korus-aq/, last access: 27 March 2019). Data were used when the DC- 8 aircraft was below $1.5 \mathrm{~km}$ a.s.l. within $1^{\circ}$ latitude and longitude of the TRF site. They are compared with the photochemical box model results in order to illustrate the relative contribution of VOCs and BVOCs on $\mathrm{O}_{3}$ production during the campaign. In both panels of Fig. 11, the case studies chosen (17 May - red, 9 June - blue) appear to be accurate representations of "typical" pollution events seen at TRF as recorded by all other days (black dots).
For isoprene, 17 May had concentrations centered around $0.5 \mathrm{ppbv}$ and were associated with $P\left(\mathrm{O}_{3}\right)$ values between 5 and $15 \mathrm{ppbv} \mathrm{h}^{-1}$. However, 9 June concentrations of isoprene were well over $0.5 \mathrm{ppbv}$, extending to over $2.0 \mathrm{ppbv}$. These were associated with $P\left(\mathrm{O}_{3}\right)$ values in excess of $20 \mathrm{ppbv} \mathrm{h}^{-1}$ and nearing $35 \mathrm{ppbv} \mathrm{h}^{-1}$, indicating that biogenic emissions contributed more to net $\mathrm{O}_{3}$ production on this day than on 17 May. The 9 June case yielded nearly the highest isoprenedriven $\mathrm{O}_{3}$ production rates during the campaign.

For toluene, 17 May appears to have several focused regions of toluene nearing $7 \mathrm{ppbv}$ mostly associated with $P\left(\mathrm{O}_{3}\right)$ at or below $15 \mathrm{ppbv} \mathrm{h}^{-1}$. However, there is a subset of toluene with concentrations between 3 and 5 ppbv that are associated with $P\left(\mathrm{O}_{3}\right)$ rates between 20 and $35 \mathrm{ppbv} \mathrm{h}^{-1}$. This is indicative of the aged urban plume associated with $\mathrm{O}_{3}$ photolysis reaching the area east of TRF. On 9 June, concentrations of toluene are nearly all below $5 \mathrm{ppbv}$ and are grouped much closer together. This is indicative of a much more wellmixed air mass (which was also suggested with the GeoTASO observations). Although 9 June was associated with a larger contribution of isoprene-driven $\mathrm{O}_{3}$ production, it had a similar concentration of toluene to 17 May, indicating that both contrasting high-pollution events (and $\left.P\left(\mathrm{O}_{3}\right)\right)$ were associated with high levels of urban pollutants.

\section{2 $\mathrm{GSFC} \mathrm{O}_{3}$ lidar-derived campaign average}

NASA GSFC $\mathrm{O}_{3}$ lidar profiles at TRF during all flight days during the KORUS-AQ campaign (Fig. 12) can be used to derive a diurnal campaign average (see Sullivan et al., 2015c). The early morning low $\mathrm{O}_{3}$ feature is prominent in the composite figure, as well as the in-air residual $\mathrm{O}_{3}$ concentrations we have linked to transboundary transport between 65 and $75 \mathrm{ppbv}$ above $500 \mathrm{~m}$ a.s.l. As solar radiation and 


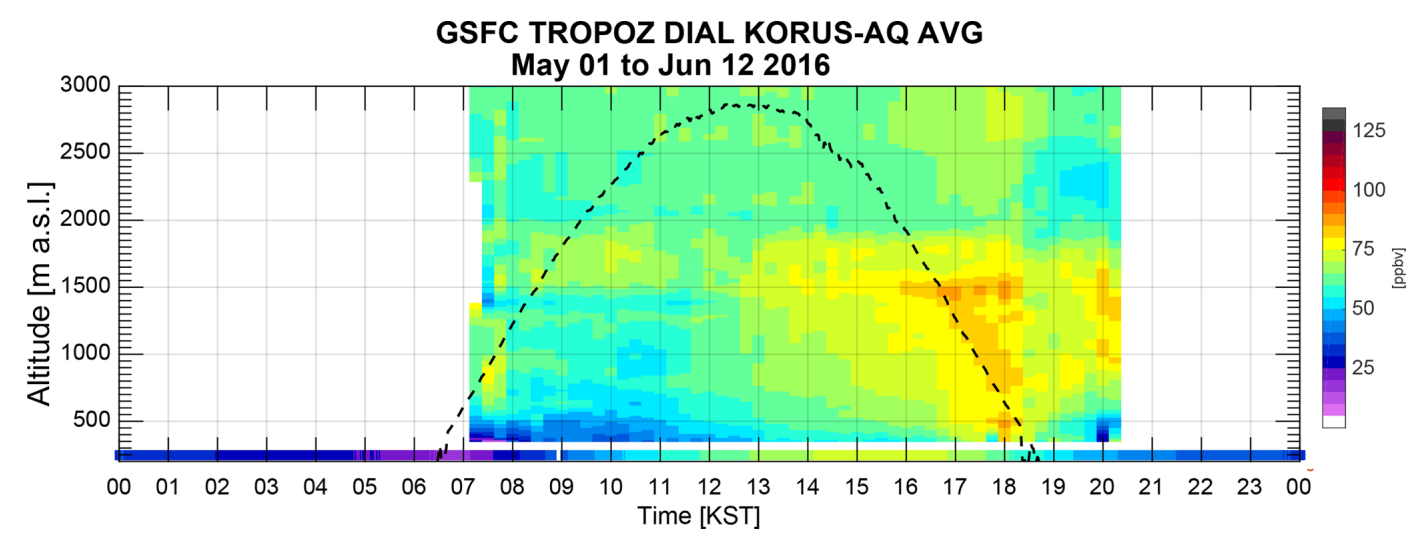

Figure 12. Composite averaged curtain of GSFC TROPOZ DIAL observations during the KORUS-AQ study period. This comprises 31 days of lidar data and over $250 \mathrm{~h}$ of measurements averaged together, and the analogous surface measurements and solar curve proxy are also overlaid.

convective mixing increase in the late morning hours (after 11:00 KST), surface concentrations of $\mathrm{O}_{3}$ correlate better with concentrations measured aloft from the lidar. In the afternoon hours, $\mathrm{O}_{3}$ increases at a rate of $5 \mathrm{ppbvh}^{-1}$ between 500 and $1500 \mathrm{~m}$ a.s.l. and peak $\mathrm{O}_{3}$ is observed between 17:00 and 18:00 KST. The difference between in-air and surface concentrations in the evening can be linked to a decoupling of the surface layer and rapid depletion and titration of surface $\mathrm{O}_{3}$ from local $\mathrm{NO}_{x}$ emissions. This process isolates the polluted in-air residual layer during nighttime hours that will potentially affect downwind locations on the following morning. This confirms that during the May-June time period, the late-day peak $\mathrm{O}_{3}$ occurrence is a persistent feature and is more enhanced than at the surface.

\section{Conclusions}

As part of the KORUS-AQ study, nearly continuous chemical measurements at the surface and within the first $3 \mathrm{~km}$ a.s.l. have quantified several of the key pollution features (e.g., residual layer $\mathrm{O}_{3}$ entrainment and late-day $\mathrm{O}_{3}$ maxima) responsible for $\mathrm{O}_{3}$ exceedances observed at a rural site downwind of Seoul. The combination of aircraft (NASA DC-8, Hanseo University King Air, and NASA B-200), in situ (surface level and balloon-borne) and remotely sensed $\left(\mathrm{O}_{3}\right.$ lidar, ceilometer) measurements, in conjunction with photochemical model simulations, have produced significant findings about the origins of pollution reaching TRF that appear to be representative of other rural sites in South Korea. Two detailed case studies have been presented, which indicate a mixture of urban-anthropogenic emissions and biogenic emissions impacting TRF. These case studies are also characteristic of the entire study (see Fig. 12), suggesting lateday $\mathrm{O}_{3}$ increases occur frequently at TRF, and that rural sites in this region may be experiencing long-term negative effects of $\mathrm{O}_{3}$. Because threshold health effects, mortality rates, and crop yield analyses have been historically calculated using only surface measurements (Lee et al., 2000; Kim et al., 2004; Wang and Mauzerall, 2004; Ghim et al., 2000), Fig. 12 also indicates that these analyses may be underestimating the extent of the negative impacts of high $\mathrm{O}_{3}$ at TRF and its surrounding rural areas.

These results clearly demonstrate that Korea is subject to highly (aged) polluted air masses that cross the Yellow Sea but are exacerbated by domestic pollution produced near SMA. This emphasizes a reevaluation of domestic emission controls, in particular reactive aromatics such as toluene (e.g., toluene not only contributes to the $P\left(\mathrm{O}_{3}\right)$ shown herein, but also contributes to $9 \%$ of modeled secondary organic aerosol over SMA; Nault et al., 2018). Organic aerosol formation has also been recently investigated during the KORUS-AQ study period to estimate relationships between in situ observations and satellite derived products (e.g., formaldehyde; Liao et al., 2019). These findings are in line with the detailed Rapid Science Synthesis Report (https://kr.usembassy.gov/wp-content/ uploads/sites/75/2017/07/KORUS-AQ-RSSR.pdf, last access: 27 March 2019) that provides findings from the KORUS-AQ study which are intended to be useful for policy makers as they develop air quality mitigation strategies and continue to identify specific emission sources that should be targeted for reduction. Direct observations of free tropospheric $\mathrm{O}_{3}$ were rarely observed below $60 \mathrm{ppbv}$ during the KORUS-AQ study period (see Figs. 4c and 12), indicating that the baseline conditions on which South Korean national regulatory standards are predicated are trending (Cooper et al., 2014) towards a regime where they are increasingly unattainable. In order to further assess transboundary pollution, emission sources, and plume evolution, there has been an international effort to launch the Geostationary Environmental Monitoring Spectrometer (GEMS) to provide hourly measurements of key pollutants (e.g., $\mathrm{O}_{3}, \mathrm{NO}_{2}, \mathrm{SO}_{2}$, and particulate matter) over the Korean 
peninsula and the Asia-Pacific region. The KORUS-AQ analyses offer an exemplary synergistic approach on how to collect the statistics required by the regulatory agencies of Korea to improve air quality in both urban and rural settings.

Data availability. Unless otherwise noted, all data used in this study are available in the KORUS-AQ data archive (http://www-air. larc.nasa.gov/missions/korus-aq/, last access: 27 March 2019).

Author contributions. JTS, TJM, RMS, AMT, LT, and GS designed and executed field measurements for collecting surface $\mathrm{O}_{3}, \mathrm{O}_{3}$ lidar, and ozonesondes at TRF. AnW provided the airborne $\mathrm{O}_{3}$ and $\mathrm{NO}_{2}$ data. ArW provided the airborne PTR-To-MS data. CK ran the FLEXPART analysis. SJ provided the GeoTASO data. RL, JS, and TK provided surface and ceilometer data. SK, DJ, and DS provided the PTR-ToF-MS data and logistical support. JRS provide the photochemical modeling analysis. JP and YL provided additional surface measurements at TRF and OLY. JTS prepared the original manuscript, and all other authors contributed in editing the paper.

Competing interests. The authors declare that they have no conflict of interest.

Acknowledgements. The KORUS-AQ study could not have been completed without the leadership and shared partnership between Korea's National Institute of Environmental Research (NIER) and the United States National Aeronautics and Space Administration (NASA). This research was supported by multiple appointments to the NASA/USRA Postdoctoral Program at the Goddard Space Flight Center Atmospheric Chemistry and Dynamics Laboratory and Langley Research Center. The authors gratefully acknowledge support provided by the NASA Tropospheric Chemistry Program and the Tropospheric Ozone Lidar Network (TOLNet). The authors would like to thank the entire KORUS-AQ science team for thoughtful discussions. We would also like to thank the pilots, captains, and crew of the Hanseo University King Air, NASA B-200, and NASA DC-8. Special thanks to Glenn Wolfe, Jason St. Clair, Reem Hannun, Jin Laio, and Thomas Hanisco for helpful discussions. PTRToF-MS measurements aboard the NASA DC-8 during KORUSAQ were supported by the Austrian Federal Ministry for Transport, Innovation and Technology (BMVIT) through the Austrian Space Applications Programme (ASAP) of the Austrian Research Promotion Agency (FFG). The PTR-MS instrument team (Phillip Eichler, Lisa Kaser, Tomáš Mikoviny, Markus Müller) is acknowledged for their support with field work and data processing. Furthermore, this work could not have been completed without the heritage of observations and existing infrastructure at the Taehwa Research Forest site, operated by the College of Agriculture and Life Sciences at Seoul National University.

Review statement. This paper was edited by Andreas Hofzumahaus and reviewed by two anonymous referees.

\section{References}

Brioude, J., Arnold, D., Stohl, A., Cassiani, M., Morton, D., Seibert, P., Angevine, W., Evan, S., Dingwell, A., Fast, J. D., Easter, R. C., Pisso, I., Burkhart, J., and Wotawa, G.: The Lagrangian particle dispersion model FLEXPART-WRF version 3.1, Geosci. Model Dev., 6, 1889-1904, https://doi.org/10.5194/gmd-6-18892013, 2013.

Choi, K.-C., Lee, J.-J., Bae, C. H., Kim, C.-H., Kim, S., Chang, L.S., Ban, S.-J., Lee, S.-J., Kim, J., and Woo, J.-H.: Assessment of transboundary ozone contribution toward South Korea using multiple source-receptor modeling techniques, Atmos. Environ., 92, 118-129, 2014.

Cooper, O. R., Parrish, D. D., Ziemke, J., Balashov, N. V., Cupeiro, M., Galbally, I. E., Gilge, S., Horowitz, L., Jensen, N. R., Lamarque, J.-F., Naik, V., Oltmans, S. J., Schwab, J., Shindell, D. T., Thompson, A. M., Thouret, V., Wang, Y., and Zbinden, R. M.: Global distribution and trends of tropospheric ozone: An observation-based review. Elem Sci Anth, 2, 000029 , https://doi.org/10.12952/journal.elementa.000029, 2014.

Duncan, B. N., Lamsal, L. N., Thompson, A. M., Yoshida, Y., Lu, Z., Streets, D. G., Hurwitz, M. M., and Pickering, K. E.: A spacebased, high-resolution view of notable changes in urban $\mathrm{NO}_{x}$ pollution around the world (2005-2014), J. Geophys. Res.Atmos., 121, 976-996, 2016.

Gelaro, R., McCarty, W., Suárez, M. J., Todling, R., Molod, A., Takacs, L., Randles, C. A., Darmenov, A., Bosilovich, M. G., Reichle, R., Wargana, K., Coy., L., Cullather, R., Draper, C., Akella, S., Buchard, V., Conaty, A., da Silva, A. M., Gu, W., Kim, G.K., Koster, R., Lucchesi, R., Merkova, D., Nielsen, J. E., Partyka, G., Pawson, S., Putman, W., Rienecker, M., Schubert, S. D., Sienkiewicz, M., and Zhao, B.: The modern-era retrospective analysis for research and applications, version 2 (MERRA-2), J. Climate, 30, 5419-5454, 2017.

Ghim, Y. S. and Chang, Y. S.: Characteristics of ground-level ozone distributions in Korea for the period of 1990-1995, J. Geophys. Res.-Atmos., 105, 8877-8890, 2000.

Ghim, Y. S., Moon, K. C., Lee, S., and Kim, Y. P.: Visibility trends in Korea during the past two decades, J. Air Waste Manage. Assoc., 55, 73-78, 2005.

He, H., Li, C., Loughner, C. P., Li, Z., Krotkov, N. A., Yang, K., Wang, L., Zheng, Y., Bao, X., Zhao, G., and Dickerson, R. R.: $\mathrm{SO}_{2}$ over central China: Measurements, numerical simulations and the tropospheric sulfur budget, J. Geophys. Res.-Atmos., 117, D16, https://doi.org/10.1029/2011JD016473, 2012.

Herman, J., Spinei, E., Fried, A., Kim, J., Kim, J., Kim, W., Cede, A., Abuhassan, N., and Segal-Rozenhaimer, $\mathrm{M} .: \mathrm{NO}_{2}$ and $\mathrm{HCHO}$ measurements in Korea from 2012 to 2016 from Pandora spectrometer instruments compared with OMI retrievals and with aircraft measurements during the KORUS-AQ campaign, Atmos. Meas. Tech., 11, 4583-4603, https://doi.org/10.5194/amt11-4583-2018, 2018.

Huang, M., Crawford, J. H., Diskin, G. S., Santanello, J. A., Kumar, S. V., Pusede, S. E., Parrington, M., and Carmichael, G. R.: Modeling Regional Pollution Transport Events During KORUS-AQ: Progress and Challenges in Improving Representation of LandAtmosphere Feedbacks, J. Geophys. Res.-Atmos., 123, 10-732, 2018.

Iqbal, M. A., Kim, K.-H., Shon, Z.-H., Sohn, J.-R., Jeon, E.-C., Kim, Y.-S., and Oh, J.-M.: Comparison of ozone pollution levels 
at various sites in Seoul, a megacity in Northeast Asia, Atmos. Res., 138, 330-345, 2014.

Jeon, W. B., Lee, S. H., Lee, H. W., and Kim, H. G.: Process analysis of the impact of atmospheric recirculation on consecutive high- $\mathrm{O}_{3}$ episodes over the Seoul Metropolitan Area in the Korean Peninsula, Atmos. Environ., 63, 213-222, 2012.

Jeon, W.-B., Lee, S.-H., Lee, H., Park, C., Kim, D.-H., and Park, S.-Y.: A study on high ozone formation mechanism associated with change of $\mathrm{NO}_{x} / \mathrm{VOCs}$ ratio at a rural area in the Korean Peninsula, Atmos. Environ., 89, 10-21, 2014.

Jeong, D., Seco, R., Gu, D., Lee, Y., Nault, B. A., Knote, C. J., Mcgee, T., Sullivan, J. T., Jimenez, J. L., Campuzano-Jost, P., Blake, D. R., Sanchez, D., Guenther, A. B., Tanner, D., Huey, L. G., Long, R., Anderson, B. E., Hall, S. R., Ullmann, K., Shin, H.-J., Herndon, S. C., Lee, Y., Kim, D., Ahn, J., and Kim, S.: Integration of Airborne and Ground Observations of Nitryl Chloride in the Seoul Metropolitan Area and the Implications on Regional Oxidation Capacity During KORUS-AQ 2016, Atmos. Chem. Phys. Discuss., https://doi.org/10.5194/acp-2018-1216, in review, 2018.

Kim, H., Zhang, Q., and Heo, J.: Influence of intense secondary aerosol formation and long-range transport on aerosol chemistry and properties in the Seoul Metropolitan Area during spring time: results from KORUS-AQ, Atmos. Chem. Phys., 18, 71497168, https://doi.org/10.5194/acp-18-7149-2018, 2018.

Kim, S.: Fast Oxidation of reactive gases in the lower troposphere above a forest downwind of an Asian megacity, Environ. Sci. Technol., in review, 2018.

Kim, S., Karl, T., Guenther, A., Tyndall, G., Orlando, J., Harley, P., Rasmussen, R., and Apel, E.: Emissions and ambient distributions of Biogenic Volatile Organic Compounds (BVOC) in a ponderosa pine ecosystem: interpretation of PTR-MS mass spectra, Atmos. Chem. Phys., 10, 1759-1771, https://doi.org/10.5194/acp-10-1759-2010, 2010.

Kim, S., Kim, S.-Y., Lee, M., Shim, H., Wolfe, G. M., Guenther, A. B., He, A., Hong, Y., and Han, J.: Impact of isoprene and HONO chemistry on ozone and OVOC formation in a semirural South Korean forest, Atmos. Chem. Phys., 15, 4357-4371, https://doi.org/10.5194/acp-15-4357-2015, 2015.

Kim, S.-W., Yoon, S.-C., Won, J.-G., and Choi, S.-C.: Ground-based remote sensing measurements of aerosol and ozone in an urban area: A case study of mixing height evolution and its effect on ground-level ozone concentrations, Atmos. Environ., 41, 70697081, 2007.

Kim, S. Y., Lee, J. T., Hong, Y. C., Ahn, K. J., and Kim, H.: Determining the threshold effect of ozone on daily mortality: an analysis of ozone and mortality in Seoul, Korea, 1995-1999, Environ. Res., 94, 113-119, 2004.

Kim, S.-Y., Seo, S.-J., Park, H.-J., Son, J.-S., Park, J.-H., and Kim, J.-C.: Airborne measurements of ozone and its precursors over Yeosu- Gwangyang industrial areas in the Southern Coast of Korea, Asian J. Atmos. Environ., 7, 139-151, 2013.

Kuang, S., Newchurch, M. J., Thompson, A. M., Stauffer, R. M., Johnson, B. J., and Wang, L.: Ozone variability and anomalies observed during SENEX and SEAC4RS campaigns in 2013, J. Geophys. Res.-Atmos., 122, 227-241, 2017.

Lee, C., Richter, A., Lee, H., Kim, Y. J., Burrows, J. P., Lee, Y. G., and Choi, B. C.: Impact of transport of sulfur dioxide from the
Asian continent on the air quality over Korea during May 2005, Atmos. Environ., 42, 1461-1475, 2008.

Lee, D.-G., Lee, Y.-M., Jang, K.-W., Yoo, C., Kang, K.-H., Lee, J.H., Jung, S.-W., Park, J.-M., Lee, S.-B., Han, J.-S., Hong, J.-H., and Lee, S.-J: Korean national emissions inventory system and 2007 air pollutant emissions, Asian J. Atmos. Environ., 5, 278291, 2011.

Lee, J.-T., Kim, H., Hong, Y.-C., Kwon, H.-J., Schwartz, J., and Christiani, D. C.: Air pollution and daily mortality in seven major cities of Korea, 1991-1997, Environ. Res., 84, 247-254, 2000.

Lee, K.-Y., Kwak, K.-H., Ryu, Y.-H., Lee, S.-H., and Baik, J.-J.: Impacts of biogenic isoprene emission on ozone air quality in the Seoul metropolitan area, Atmos. Environ., 96, 209-219, 2014.

Lennartson, E. M., Wang, J., Gu, J., Castro Garcia, L., Ge, C., Gao, M., Choi, M., Saide, P. E., Carmichael, G. R., Kim, J., and Janz, S. J.: Diurnal variation of aerosol optical depth and $\mathrm{PM}_{2.5}$ in South Korea: a synthesis from AERONET, satellite (GOCI), KORUS-AQ observation, and the WRF-Chem model, Atmos. Chem. Phys., 18, 15125-15144, https://doi.org/10.5194/acp-1815125-2018, 2018.

Liao, J., Hanisco, T. F., Wolfe, G. M., St. Clair, J., Jimenez, J. L., Campuzano-Jost, P., Nault, B. A., Fried, A., Marais, E. A., Gonzalez Abad, G., Chance, K., Jethva, H. T., Ryerson, T. B., Warneke, C., and Wisthaler, A.: Towards a satellite formaldehyde - in situ hybrid estimate for organic aerosol abundance, Atmos. Chem. Phys., 19, 2765-2785, https://doi.org/10.5194/acp19-2765-2019, 2019.

Lim, Y.-J., Armendariz, A., Son, Y.-S., and Kim, J.-C.: Seasonal variations of isoprene emissions from five oak tree species in East Asia, Atmos. Environ., 45, 2202-2210, 2011.

Miyazaki, K., Eskes, H. J., Sudo, K., Takigawa, M., van Weele, M., and Boersma, K. F.: Simultaneous assimilation of satellite $\mathrm{NO}_{2}$, $\mathrm{O}_{3}, \mathrm{CO}$, and $\mathrm{HNO}_{3}$ data for the analysis of tropospheric chemical composition and emissions, Atmos. Chem. Phys., 12, 95459579, https://doi.org/10.5194/acp-12-9545-2012, 2012.

Miyazaki, K., Sekiya, T., Fu, D., Bowman, K., Kulawik, S., Sudo, K., Walker, T., Kanaya, Y., Takigawa, M., Ogochi, K., Eskes, H., Boersma, K. F., Thompson, A. M., Gaubert, B., Barre, J., and Emmons, L. K.: Balance of emission and dynamical controls on ozone during KORUS-AQ from multi-constituent satellite data assimilation, J. Geophys. Res.-Atmos., 124, 387-413, 2018.

Müller, M., Mikoviny, T., Feil, S., Haidacher, S., Hanel, G., Hartungen, E., Jordan, A., Märk, L., Mutschlechner, P., Schottkowsky, R., Sulzer, P., Crawford, J. H., and Wisthaler, A.: A compact PTR-ToF-MS instrument for airborne measurements of volatile organic compounds at high spatiotemporal resolution, Atmos. Meas. Tech., 7, 3763-3772, https://doi.org/10.5194/amt-7-37632014, 2014.

Nault, B. A., Campuzano-Jost, P., Day, D. A., Schroder, J. C., Anderson, B., Beyersdorf, A. J., Blake, D. R., Brune, W. H., Choi, Y., Corr, C. A., de Gouw, J. A., Dibb, J., DiGangi, J. P., Diskin, G. S., Fried, A., Huey, L. G., Kim, M. J., Knote, C. J., Lamb, K. D., Lee, T., Park, T., Pusede, S. E., Scheuer, E., Thornhill, K. L., Woo, J.-H., and Jimenez, J. L.: Secondary organic aerosol production from local emissions dominates the organic aerosol budget over Seoul, South Korea, during KORUS-AQ, Atmos. Chem. Phys., 18, 17769-17800, https://doi.org/10.5194/acp-18-177692018, 2018. 
Nowlan, C. R., Liu, X., Leitch, J. W., Chance, K., González Abad, G., Liu, C., Zoogman, P., Cole, J., Delker, T., Good, W., Murcray, F., Ruppert, L., Soo, D., Follette-Cook, M. B., Janz, S. J., Kowalewski, M. G., Loughner, C. P., Pickering, K. E., Herman, J. R., Beaver, M. R., Long, R. W., Szykman, J. J., Judd, L. M., Kelley, P., Luke, W. T., Ren, X., and AlSaadi, J. A.: Nitrogen dioxide observations from the Geostationary Trace gas and Aerosol Sensor Optimization (GeoTASO) airborne instrument: Retrieval algorithm and measurements during DISCOVER-AQ Texas 2013, Atmos. Meas. Tech., 9, 26472668, https://doi.org/10.5194/amt-9-2647-2016, 2016.

Ryu, Y.-H., Baik, J.-J., Kwak, K.-H., Kim, S., and Moon, N.: Impacts of urban land-surface forcing on ozone air quality in the Seoul metropolitan area, Atmos. Chem. Phys., 13, 2177-2194, https://doi.org/10.5194/acp-13-2177-2013, 2013.

Schroeder, J. R., Crawford, J. H., Fried, A., Walega, J., Weinheimer, A., Wisthaler, A., Müller, M., Mikoviny, T., Chen, G., Shook, M., Blake, D. R., Diskin, G., Estes, M., Thompson, A. M. Lefer, B., L., Long, R., and Mattson, E.: Formaldehyde column density measurements as a suitable pathway to estimate near-surface ozone tendencies from space, J. Geophys. Res.-Atmos., 121, 13088-13112, 2016.

Seo, J., Youn, D., Kim, J. Y., and Lee, H.: Extensive spatiotemporal analyses of surface ozone and related meteorological variables in South Korea for the period 1999-2010, Atmos. Chem. Phys., 14, 6395-6415, https://doi.org/10.5194/acp-14-6395-2014, 2014.

Stauffer, R. M., Thompson, A. M., and Young, G. S.: Tropospheric ozonesonde profiles at long-term US monitoring sites: 1. A climatology based on self-organizing maps, J. Geophys. Res.Atmos., 121, 1320-1339, 2016.

Sullivan, J. T., McGee, T. J., Sumnicht, G. K., Twigg, L. W., and Hoff, R. M.: A mobile differential absorption lidar to measure sub-hourly fluctuation of tropospheric ozone profiles in the Baltimore-Washington, D.C. region, Atmos. Meas. Tech., 7, 3529-3548, https://doi.org/10.5194/amt-7-3529-2014, 2014.

Sullivan, J. T., McGee, T. J., De Young, R., Sumnicht, G. K., Twigg, L. W., Pliutau, D., Carrion, W., and Knepp, T.: Results from the NASA GSFC and LaRC ozone lidar intercomparison: New mobile tools for atmospheric research, J. Atmos. Ocean. Tech., 32, 1779-1795, 2015a.

Sullivan, J. T., McGee, T. J., Leblanc, T., Sumnicht, G. K., and Twigg, L. W.: Optimization of the GSFC TROPOZ DIAL retrieval using synthetic lidar returns and ozonesondes - Part 1: Algorithm validation, Atmos. Meas. Tech., 8, 4133-4143, https://doi.org/10.5194/amt-8-4133-2015, 2015 b.

Sullivan, J. T., McGee, T. J., Thompson, A. M., Pierce, R. B., Sumnicht, G. K., Twigg, L. W., Eloranta, E., and Hoff, R. M.: Characterizing the lifetime and occurrence of stratospherictropospheric exchange events in the rocky mountain region using high-resolution ozone measurements, J. Geophys. Res.-Atmos., 120, 12410-12424, 2015c.
Sullivan, J. T., McGee, T. J., Langford, A. O., Alvarez, R. J., Senff, C. J., Reddy, P. J., Thompson, A. M., Twigg, L. W., Sumnicht, G. K., Lee, P., Weinheimer, A., Knote, C., Long, R. W., and Hoff, R. M.: Quantifying the contribution of thermally driven recirculation to a high-ozone event along the Colorado Front Range using lidar, J. Geophys. Res.-Atmos., 121, 10-377, 2016.

Sullivan, J. T., Rabenhorst, S. D., Dreessen, J., McGee, T. J., Delgado, R., Twigg, L., and Sumnicht, G.: Lidar observations revealing transport of $\mathrm{O}_{3}$ in the presence of a nocturnal low-level jet: Regional implications for "next-day" pollution, Atmos. Environ., 158, 160-171, 2017.

Thompson, A. M., Witte, J. C., Smit, H. G., Oltmans, S. J., Johnson, B. J., Kirchhoff, V. W., and Schmidlin, F. J.: Southern Hemisphere Additional Ozonesondes (SHADOZ) 1998-2004 tropical ozone climatology: 3 . Instrumentation, station-to-station variability, and evaluation with simulated flight profiles, J. Geophys. Res.-Atmos., 112, D3, 2007.

Thompson, A. M., Smit, H. G., Witte, J. C., Stauffer, R. M., Johnson, B. J., Morris, G., von der Gathen, P., Van Malderen, R., Davies, J., Piters, A., Allaart, M., Posny, F., Kivi, R., Cullis, P., Hoang Anh, N. T., Corrales, E., Machinini, T., da Silva, F. R., Paiman, G., Thiongó, K., Zainal, Z., Brothers, G. B., Wolff, K. R., Nakano, T., Stübi, R., Romanens, G., Coetzee, G. J., Diaz, J. A., Mitro, S., Mohamad, M., and Ogino, S.: Ozonesonde Quality Assurance: The JOSIESHADOZ (2017) Experience, Bull. Amer. Meteor. Soc., 100, 155-171, https://doi.org/10.1175/BAMS-D-17-0311.1, 2019.

Vellingiri, K., Kim, K.-H., Jeon, J. Y., Brown, R. J., and Jung, M.C.: Changes in $\mathrm{NO}_{x}$ and $\mathrm{O}_{3}$ concentrations over a decade at a central urban area of Seoul, Korea, Atmos. Environ., 112, 116$125,2015$.

Wang, S. X., Zhao, B., Cai, S. Y., Klimont, Z., Nielsen, C. P., Morikawa, T., Woo, J. H., Kim, Y., Fu, X., Xu, J. Y., Hao, J. M., and He, K. B.: Emission trends and mitigation options for air pollutants in East Asia, Atmos. Chem. Phys., 14, 6571-6603, https://doi.org/10.5194/acp-14-6571-2014, 2014.

Wang, X. and Mauzerall, D. L.: Characterizing distributions of surface ozone and its impact on grain production in China, Japan and South Korea: 1990 and 2020, Atmos. Environ., 38, 43834402, 2004.

Weinheimer, A. J.: Chemical methods: chemiluminescence, chemical amplification, electrochemistry, and derivatization, Analytical Techniques for Atmospheric Measurement, 311 pp., 2006.

Witte, J. C., Thompson, A. M., Smit, H. G., Fujiwara, M., Posny, F., Coetzee, G. J., Northam, E. T., Johnson, B. J., Sterling, C. W., Mohamad, M., and Ogino, S. Y.: First reprocessing of Southern Hemisphere ADditional OZonesondes (SHADOZ) profile records (1998-2015): 1. Methodology and evaluation, J. Geophys. Res.-Atmos., 122, 6611-6636, 2017.

Zhao, Y., Wang, S., Duan, L., Lei, Y., Cao, P., and Hao, J.: Primary air pollutant emissions of coal-fired power plants in China: Current status and future prediction, Atmos. Environ., 42, 84428452, 2008. 